Article

\title{
Observations and Predictability of Gap Winds in the Salmon River Canyon of Central Idaho, USA
}

\author{
Natalie S. Wagenbrenner ${ }^{1, *}$, Jason M. Forthofer ${ }^{1}$, Chris Gibson ${ }^{2}$, Abby Indreland ${ }^{1}$, \\ Brian K. Lamb ${ }^{3}$ and Bret W. Butler ${ }^{1}$ \\ 1 US Forest Service, Rocky Mountain Research Station, Missoula Fire Sciences Laboratory, 5775 W Highway 10, \\ Missoula, MT 59808, USA; jaforthofer@fs.fed.us (J.M.F.); aindreland@mtech.edu (A.I.); \\ bwbutler@fs.fed.us (B.W.B.) \\ 2 National Oceanic and Atmospheric Administration, National Weather Service, Missoula, MT 59808, USA; \\ chris.gibson@noaa.gov \\ 3 Washington State University, Laboratory for Atmospheric Research, Pullman, WA 99164, USA; \\ blamb@wsu.edu \\ * Correspondence: nwagenbrenner@fs.fed.us
}

Received: 30 November 2017; Accepted: 29 January 2018; Published: 31 January 2018

\begin{abstract}
This work investigates gap winds in a steep, deep river canyon prone to wildland fire. The driving mechanisms and the potential for forecasting the gap winds are investigated. The onset and strength of the gap winds are found to be correlated to the formation of an along-gap pressure gradient linked to periodic development of a thermal trough in the Pacific Northwest, USA. Numerical simulations are performed using a reanalysis dataset to investigate the ability of numerical weather prediction (NWP) to simulate the observed gap wind events, including the timing and flow characteristics within the canyon. The effects of model horizontal grid spacing and terrain representation are considered. The reanalysis simulations suggest that horizontal grid spacings used in operational NWP could be sufficient for simulating the gap flow events given the regional-scale depression in which the Salmon River Canyon is situated. The strength of the events, however, is under-predicted due, at least in part, to terrain smoothing in the model. Routine NWP, however, is found to have mixed results in terms of forecasting the gap wind events, primarily due to problems in simulating the regional sea level pressure system correctly.
\end{abstract}

Keywords: gap wind; complex terrain; numerical weather prediction

\section{Introduction}

Horizontal pressure gradients can produce strong winds in mountain passages under otherwise quiescent conditions. The affected passages vary widely in scale and geometry and include gaps (terrain openings connecting mountain ranges), canyons or channels, passes, and straits. Flow induced by an along-passage pressure gradient is referred to as pressure-driven channeling (e.g., [1]). The cause of the pressure gradient and the resulting flow signature can vary from site-to-site according to the local terrain geometry and atmospheric conditions; however, the general mechanism and flow characteristics are similar among sites. Pressure-driven flow through a terrain gap is also referred to as a "gap wind" [2]. In this work, we investigate gap winds observed in the Salmon River Canyon, a narrow, deep gap surrounded by complex terrain, during a 2011 surface wind field campaign [3].

An along-gap pressure gradient can form due to processes at various scales. A pressure gradient may form due to local forces (e.g., differences in surface heating and cooling at either end of the gap), convective-scale forces (e.g., thunderstorm outflows), or synoptic-scale forces (e.g., traveling pressure systems). These forces can also interact to drive the horizontal pressure gradient and resulting flow across the gap. The strongest gap winds tend to form under stable atmospheric conditions, 
when near-surface winds are decoupled from flows aloft, and the pressure gradient is strong along the gap. Strong gap winds can interrupt or overwhelm mountain diurnal winds [2].

The wide range of scales which can affect the generation of the horizontal pressure gradient and the large site-to-site variability of mountain gaps make it difficult to extrapolate observations and forecasting techniques from one location to another. Additional investigations, particularly in gaps with configurations that have not been thoroughly explored, will lead to a better understanding of gap winds for classes of similar gaps. The best-studied gap flows have typically been in relatively large gaps near major population centers, such as the Columbia River Gorge (e.g., [4]), Brenner Pass (e.g., [5]), and the Strait of Juan de Fuca (e.g., [6]). Fewer investigations have been conducted for narrower gaps, such as the Salmon River Canyon.

Gap winds can have substantial impacts on the local climatology [4], transport and dispersion of pollutants [7], cloud formation [8], aviation operations [9], and wildland fire behavior [10,11]. The gap investigated in this work, the Salmon River Canyon in central Idaho, USA, experiences frequent wildfire activity. There were 14 large wildfires in the canyon during $2000-2015$. Roughly $80 \%$ of the Salmon River corridor has burned at least once since 2000 according to the Monitoring Trends in Burn Severity (MTBS84) dataset [12]. Gap winds could surprise firefighters given their timing (morning time, which is usually characterized by a transition to upslope/upvalley flow) and strength if they are not forecast by operational models or local meteorologists. Gap winds in the canyon, therefore, have practical implications for wildland firefighting operations and firefighter safety in the region. Unlike many previously studied gaps, the Salmon River Canyon is a remote, deep, narrow canyon surrounded by rugged terrain in all directions. The discovery of strong gap winds in this canyon is particularly important for firefighting operations given the difficult access and rugged terrain.

Gap winds can be forecast by numerical weather prediction (NWP) models if regional near-surface pressure patterns are correctly simulated, the gap is wide enough to be resolved by the model, and the model has sufficient vertical resolution near the surface to resolve the gap flow layer. The horizontal grid spacing determines what terrain features are resolved in the model. Six to eight grid cells are needed to adequately resolve a given terrain feature within the model [13]. Gap flows through large gaps (e.g., $>18 \mathrm{~km}$ wide, such as the Strait of Juan de Fuca in the U.S.) can often be forecast explicitly by operational high-resolution (3-4 km horizontal grid spacing) NWP models. Gap flows through narrower gaps such as the Salmon River Canyon (1-2 km wide) presumably require modeling at a higher horizontal resolution than what is typically used in operational NWP (e.g., $3 \mathrm{~km}$ is the smallest grid spacing used for operational NWP in the U.S.). In the absence of higher resolution modeling, there is also potential to use forecast sea level pressures across the gap (e.g., [2]) to estimate the onset and strength of gap wind events.

Here we investigate the gap winds identified in Butler et al. [3] including the driving mechanism and the potential for forecasting. The correlation between gap winds and formation of an along-gap pressure gradient linked to periodic development of a thermal trough in the Pacific Northwest is investigated. Numerical simulations are performed to investigate the ability of NWP to simulate the observed gap wind events, including the timing and flow characteristics within the canyon. The effects of model horizontal grid spacing and terrain representation are considered. The findings from this work are important for wildland fire applications in the Salmon River Canyon and other similar deep, narrow canyons.

\section{Methods}

\subsection{Geographic Location, Terrain, and Observed Winds}

The study area and observed wind regimes are described in detail in Butler et al. [3]. Here, we provide an overview of those descriptions and expand on them to include the greater Salmon River Canyon and surrounding terrain upstream of the study area. 
The Salmon River originates in eastern Idaho near the Montana border and drains the Clearwater and Selway-Bitterroot mountains (elevations $>3000 \mathrm{~m}$ ) to the north and south of the river (Figure 1). The canyon runs predominantly east-west, until it reaches Riggins, Idaho, where it makes a 90 degree turn to run north, paralleling the Oregon border. East of Riggins, the canyon is narrow, roughly $1000 \mathrm{~m}$ deep, and highly dissected by smaller drainages. The canyon opens up considerably in Riggins where it bends north and the Little Salmon River joins it from the south. North of Riggins, the river is bordered on the west by mountains running north-south which divide the Salmon River from the Snake River until the two converge roughly $50 \mathrm{~km}$ north. The river canyon immediately north of Riggins is much wider than upstream. The basin in Riggins, roughly $10 \mathrm{~km}$ west of our study area, is the first major opening of the constricted canyon in over $200 \mathrm{~km}$. The canyon is comprised of timber in the upper elevations, grasses in the lower elevations, and exposed bedrock.

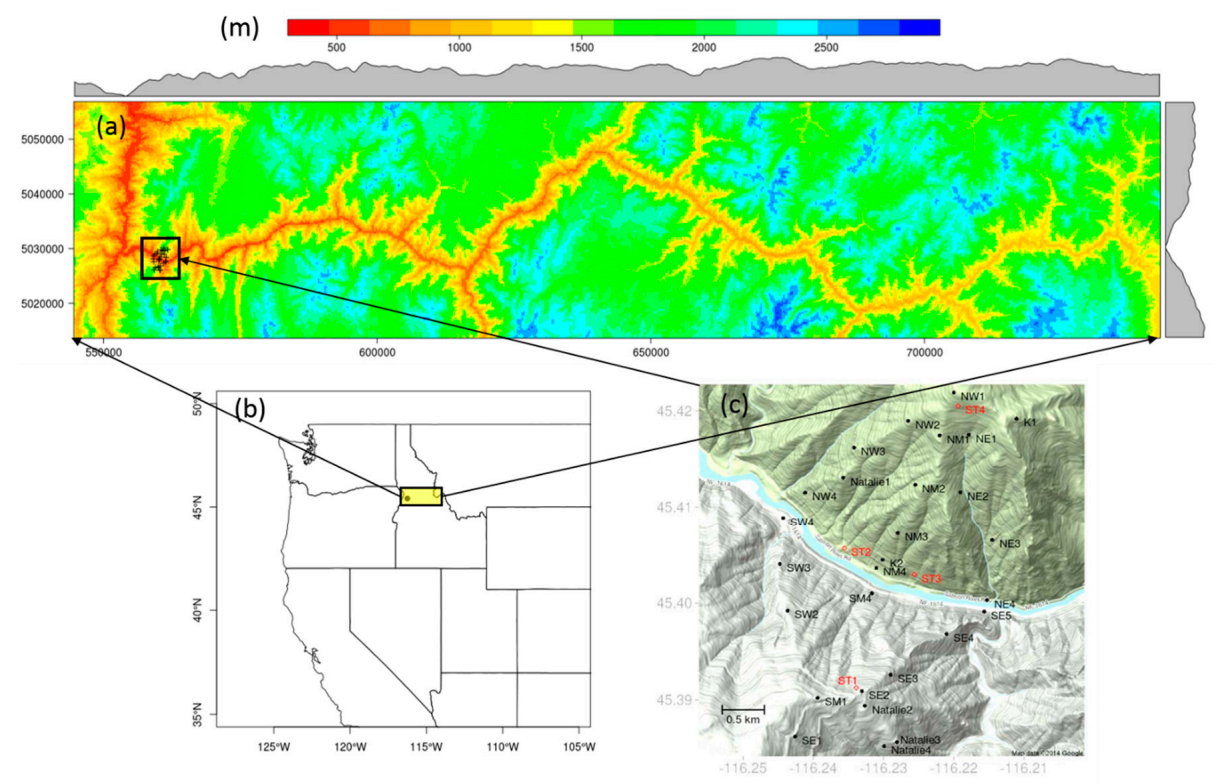

Figure 1. Study area and surrounding terrain. (a) Digital elevation model of the Salmon River Canyon and surrounding terrain; the small black crosses indicate wind sensor locations. (b) Geographic location of the Salmon River Canyon; the yellow box denotes the location Salmon River Canyon; the black circle indicates the study area. (c) Hillshade of the study area with wind sensor locations.

The Butler et al. [3] study area $\left(45.402^{\circ},-116.23^{\circ}\right)$ covers a $5 \mathrm{~km}$ long stretch of river approximately $10 \mathrm{~km}$ east (upstream) of Riggins (Figure 1) and spans in elevation from the canyon bottom (550 m) to the nearest ridgetops $(1600 \mathrm{~m})$. Wind sensor locations were chosen to characterize near-surface winds within the study area, including the micro-scale effects of the canyon terrain. The extent (several $\mathrm{km}$ ) and spacing (100 s of $\mathrm{m}$ ) of the sensors was chosen to provide a dataset that could be used to evaluate wind predictions from both diagnostic micro-scale and high-resolution NWP models and to ensure feasible maintenance as the canyon is remote and rugged, making access to the sensors strenuous and time consuming. The timing and duration of the observations was chosen so that a range of typical fire season meteorological conditions could be sampled. The predominant vegetation is grass with some timber in the higher elevations on the north aspects. Measurements were made during 16 July-13 September 2011. The river is the dividing line between the Mountain and Pacific Time Zones. For clarity we report all times in Mountain Daylight Time and refer to this as Local Time (LT).

Butler et al. [3] identified two wind regimes in the study area: a thermally-driven diurnal regime and a synoptically-forced regime, which included periods of pressure-driven, downvalley winds (gap winds). Figure 2 shows winds observed during typical diurnal (downslope and upslope) and gap wind periods. 


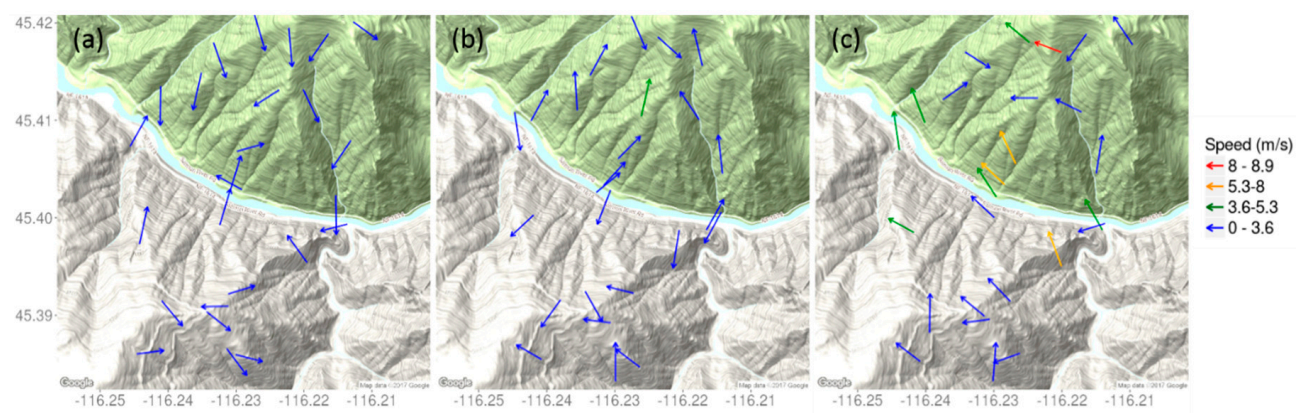

Figure 2. (a) Downslope winds at 0100 LT on 11 August 2011; (b) upslope winds at 1100 LT on 11 August 2011; and (c) gap winds at 1000 LT on 17 August 2011.

The diurnal cycle was characterized by upslope winds during 0900 to 1500 LT and a transition to upvalley winds around 1500 LT, which lasted until about 1900 LT. Subsequently, there was a transition to downslope winds which lasted until about 0700 LT. The average wind speed measured during the diurnal cycle was $2.0 \mathrm{~m} \mathrm{~s}^{-1}$ and the highest wind speed measured during the diurnal cycle was $4.2 \mathrm{~m} \mathrm{~s}^{-1}$.

Gap winds were characterized by an increase in wind speed and consistent easterly flow and typically began around 0500 LT and ended by 1200 LT. The gap winds overpowered the normal diurnal cycle during this period, but the diurnal flow regime re-established once the gap wind ceased (usually by 1200 LT). The gap winds were the strongest winds observed in the study area with wind speeds up to $15 \mathrm{~m} \mathrm{~s}^{-1}$. The easterly gap wind events pushed the onset of upslope/upvalley flow from 0900 LT back to 1200 or 1300 LT. The highest winds were observed at the mid- and upper-elevation sensors, which is consistent with gap flow prototypes proposed by Armi and Mayr [5].

Butler et al. [3] noted that the gap wind events coincided with periods of an east-west sea level pressure gradient (higher pressure to the east) along the length of the Salmon River Canyon. Here we quantify that pressure gradient and its correlation to the strength of the observed gap flow events. We also investigate the link between the east-west pressure gradient and a surface pressure low that intermittently forms in the Pacific Northwest during summertime [2,14,15]. At the onset of the gap wind events (usually around 0500 LT), the synoptic-scale horizontal sea level pressure gradient and local-scale, thermally-induced horizontal pressure gradient are aligned. Because of this alignment, it is suspected that the gap winds are enhanced by the nighttime katabatic flow persisting from the previous night.

The following are typical characteristics of gap winds: an along-gap wind that is stronger than the diurnal winds, lack of a jet-like profile, lack of flow reversal at the usual morning transition time, and a favorable along-gap pressure gradient (e.g., [1]). All of these characteristics are observed during the gap winds in the study area.

\subsection{Classification of Gap Wind Events}

To classify gap wind events, we screen the data for periods during which easterly (downvalley) flow is consistently measured at a majority of the sensor locations during roughly 0500-1200 LT. We specify that the wind be downvalley at a "majority of the sensor locations" because some sensors never have a consistent easterly component, likely due to smaller-scale flow features induced by the local terrain (e.g., side drainages, side wall bifurcations, etc.). The classified gap wind event days are referred to as "event days" and the days not classified as event days are referred to as "non-event days".

\subsection{Calculation of the Sea Level Pressure Gradient}

Sea level pressures from ERA-Interim at the European Center for Medium-Range Weather Forecasting (ECMWF) [16], National Center for Environmental Prediction/National Center for 
Atmospheric Research (NCEP/NCAR) [17], and NCEP North American Regional Reanalysis (NARR) [18] reanalyses are used to calculate the mean sea level pressure gradient across the length of the Salmon River Canyon, from the Montana border to the Oregon border (Figure 1). The horizontal grid spacing of these reanalysis datasets is coarse $(80,210$ and $32 \mathrm{~km}$ grid spacing) compared to the scale of the study area; however, our hypothesis is that the observed gap wind events are canyon-scale events tied to the regional sea level pressure gradient. The horizontal grid spacings of the reanalysis datasets are adequate for testing this relationship between the gap winds and the regional sea level pressure gradient.

The sea level pressure at $0600 \mathrm{LT}$ is extracted at either end of a $240-\mathrm{km}$ east-west transect following the canyon. These values are used to calculate an average sea level pressure gradient along the canyon for each day of the study period. The ECMWF model on which the ERA-Interim reanalysis is based has been shown to outperform other models in terms of sea level pressure forecast skill [19]. The calculated sea level pressure gradients are similar between the reanalyses; however, the ERA-Interim reanalysis provided the best correlation with gap wind strength. Here we only report the pressure gradients calculated based on the ERA-Interim reanalysis (Table 1).

Linear regressions are performed to investigate the predictability of gap wind strength at sensor NM3 based the on the sea level pressure gradient at 0600 LT. Sensor NM3 was used because it provided the best correlation with the sea level pressure gradient. Sea level pressure gradients at 0900 and 1200 LT were also investigated, but the gradient at $0600 \mathrm{LT}$ was found to be the best predictor and is used in this analysis. Cloud cover was also investigated as a predictor, but did not improve regressions and is not included in this analysis.

Table 1. Wind speed and direction measured at NM3 and calculated sea level pressure gradients from the ERA-Interim reanalysis during gap wind event days. NM3 was located on the north canyon wall about one-third of the way up. Average direction and maximum speed are reported for 0500-1200 LT. Average speeds are wind speeds averaged over the specified hour. Maximum speeds are the maximum instantaneous speeds observed (30-s averages).

\begin{tabular}{|c|c|c|c|c|c|c|}
\hline Date & $\begin{array}{c}\text { Average } \\
\text { Direction }\left({ }^{\circ}\right)\end{array}$ & $\begin{array}{c}\text { Maximum } \\
\text { Speed }\left(\mathrm{m} \mathrm{s}^{-1}\right)\end{array}$ & $\begin{array}{c}\text { Average } \\
\text { Speed }\left(\mathrm{m} \mathrm{s}^{-1}\right) \\
(0600 \mathrm{LT})\end{array}$ & $\begin{array}{c}\text { Average } \\
\text { Speed }\left(\mathrm{m} \mathrm{s}^{-1}\right) \\
(0900 \mathrm{LT})\end{array}$ & $\begin{array}{c}\text { Average } \\
\text { Speed }\left(\mathrm{m} \mathrm{s}^{-1}\right) \\
(1200 \mathrm{LT})\end{array}$ & $\begin{array}{l}\text { Pressure Gradient } \\
\left(\mathrm{Pa} \mathrm{km}^{-1}\right)(0600 \mathrm{LT})\end{array}$ \\
\hline 16 July 2011 & 150 & 10 & 0.7 & 5.6 & 1.8 & 1.0 \\
\hline 17 July 2011 & 142 & 5.9 & 2.6 & 3.3 & 2.8 & 1.1 \\
\hline 24 July 2011 & 141 & 9.8 & 4.1 & 6.7 & 5.3 & 1.2 \\
\hline 30 July 2011 & 143 & 8.4 & 2.9 & 3.3 & 1.1 & 1.1 \\
\hline 1 August 2011 & 153 & 6.3 & 3.6 & 3.2 & 2.8 & 0.2 \\
\hline 2 August 2011 & 168 & 7.1 & 1.2 & 1.0 & 2.3 & 1.1 \\
\hline 4 August 2011 & 156 & 11 & 1.4 & 4.6 & 1.8 & 0.6 \\
\hline 5 August 2011 & 145 & 12 & 2.7 & 3.8 & 3.8 & 1.3 \\
\hline 6 August 2011 & 144 & 7.8 & 1.3 & 3.5 & 3.2 & 0.7 \\
\hline 13 August 2011 & 140 & 9.9 & 2.5 & 5.0 & 6.6 & 1.3 \\
\hline 16 August 2011 & 144 & 6.5 & 1.5 & 3.1 & 3.2 & 0.7 \\
\hline 17 August 2011 & 141 & 8.9 & 3.1 & 6.0 & 5.0 & 0.7 \\
\hline 20 August 2011 & 141 & 5.9 & 2.1 & 2.8 & 2.8 & 0.8 \\
\hline 21 August 2011 & 136 & 9.7 & 3.5 & 4.5 & 4.9 & 0.6 \\
\hline 22 August 2011 & 137 & 10 & 4.2 & 6.3 & 4.6 & 0.9 \\
\hline 24 August 2011 & 129 & 11 & 2.6 & 6.5 & 6.3 & 0.9 \\
\hline 25 August 2011 & 164 & 7.8 & 3.3 & 1.1 & 2.0 & 0.6 \\
\hline 26 August 2011 & 136 & 7.1 & 1.8 & 3.5 & 4.2 & 1.1 \\
\hline 28 August 2011 & 126 & 7.1 & 1.9 & 3.1 & 5.0 & 1.2 \\
\hline 29 August 2011 & 132 & 7.1 & 4.7 & 3.5 & 2.3 & 0.3 \\
\hline 3 September2011 & 148 & 7.2 & 0.4 & 3.4 & 2.5 & 0.7 \\
\hline 4 September 2011 & 131 & 11 & 4.1 & 6.3 & 6.4 & 1.4 \\
\hline 5 September 2011 & 145 & 5.8 & 4.8 & 7.1 & 6.4 & 1.1 \\
\hline 6 September 2011 & 156 & 4.6 & 1.0 & 3.3 & 3.3 & 0.8 \\
\hline 7 September 2011 & 136 & 10 & 5.6 & 6.7 & 6.3 & 1.5 \\
\hline 8 September 2011 & 137 & 11 & 6.1 & 6.5 & 6.3 & 1.8 \\
\hline 9 September 2011 & 150 & 7.4 & 0.8 & 2.8 & 3.6 & 1.2 \\
\hline 10 September 2011 & 150 & 6.7 & 4.5 & 6.3 & 4.4 & 1.6 \\
\hline 11 September 2011 & 134 & 9.5 & 4.2 & 7.7 & 5.2 & 1.4 \\
\hline 12 September 2011 & 140 & 8.9 & 3.4 & 4.8 & 4.7 & 1.5 \\
\hline 13 September 2011 & 150 & 5.4 & 0.8 & 4.8 & 4.3 & 1.1 \\
\hline
\end{tabular}




\subsection{Numerical Model Setup}

The Advanced Research Version of the Weather Research and Forecasting (WRF-ARW) model, version 3.8, is used for numerical simulations. WRF is a non-hydrostatic NWP model that solves the compressible Navier-Stokes equations using finite difference discretization techniques [13].

Four one-way nested domains are used for the simulations. The outermost domain (d01) has a horizontal grid spacing of $36 \mathrm{~km}$ and covers the U.S. Pacific Northwest. The outermost domain is nested down to a domain with $12 \mathrm{~km}$ horizontal grid spacing (d02) covering most of Idaho and parts of neighboring states. The $12 \mathrm{~km}$ domain is nested down to a domain with $4 \mathrm{~km}$ horizontal grid spacing (d03) covering central Idaho. The $4 \mathrm{~km}$ domain is nested down to a domain with $1.33 \mathrm{~km}$ horizontal grid spacing ( $\mathrm{d} 04)$ covering the study area and upper Salmon River Canyon. The domains have 33 vertical levels with a model top height around 10,000 Pa. For brevity we refer to the domains as the " $36 \mathrm{~km}$ ", " $12 \mathrm{~km}$ ", " $4 \mathrm{~km}$ " and " $1.33 \mathrm{~km}$ " domains.

The $4 \mathrm{~km}$ domain completely covers the Salmon River Canyon and surrounding terrain. The $1.33 \mathrm{~km}$ domain was positioned to include the study area as well as a portion of the Salmon River Canyon upstream of the study area. The study area is near the western edge of the $1.33 \mathrm{~km}$ domain, but there are more than seven grid cells between the study area and the western domain boundary.

The following parameterizations are used: Noah Land Surface Model [20], Thompson microphysics [21], Kain-Fritsch convective scheme [22] (except in the $1.33 \mathrm{~km}$ domain), Rapid Radiative Transfer Model (RRTM) for longwave radiation [23], Dudhia [24] for shortwave radiation, Monin-Obukhov similarity scheme [25] at the surface, and the Yonsei University (YSU) boundary layer scheme [26]. No convective scheme is used in the $1.33 \mathrm{~km}$ domain. The model settings used in this work were chosen to be representative of current operational NWP modeling in the U.S. Pacific Northwest (e.g., [27]). A sensitivity analysis investigating the effects of the various settings (physics options, vertical layer placement, etc.) on model results would be interesting, but is beyond the scope of the current work.

Global Multi-resolution Terrain Elevation Data (GMTED2010) at 30 arc-second ( $900 \mathrm{~m}$ ) resolution are used for all but the $36 \mathrm{~km}$ domain, which uses 10 arc-minute terrain data. Because unresolved terrain features can generate forcings that are not properly resolved by the model and which can decrease computational stability, it is often recommended that terrain smoothing be used to filter features not resolved by the model. Skamarock [28] reported a WRF model effective resolution of seven times the model horizontal grid spacing, which means a $1.33 \mathrm{~km}$ domain has an effective resolution of about $9.3 \mathrm{~km}$. In this work, the resolution of the terrain data $(900 \mathrm{~m})$ is 10.3 times higher than the model effective resolution for the $1.33 \mathrm{~km}$ domain $(7 \times 1.33 \mathrm{~km}=9310 \mathrm{~m})$, and 93 times higher than the model effective resolution for the $12 \mathrm{~km}$ domain $(7 \times 12 \mathrm{~km}=84,000 \mathrm{~m})$. To address this issue, we performed simulations with and without terrain smoothing. There were no appreciable differences between the smoothed and unsmoothed simulations in the study area, so here we only present the unsmoothed results.

The $36 \mathrm{~km}$ domain is initialized with NARR data. The NARR was used because NARR sea level pressure gradients compared well with the ERA-Interim sea level pressure gradients during the simulation period and we were already set up to initialize WRF with NARR data. It could be interesting to investigate results from initialization with other datasets in the future. The time step for the $1.33 \mathrm{~km}$ domain is $8.9 \mathrm{~s}$. Analysis nudging (e.g., [29]) is used above the boundary layer in the outer-most (36 km) domain. Simulations are run for 15-19 August 2011 with $12 \mathrm{~h}$ of model spin-up and the output is written hourly. This period was chosen because it contains both event and non-event days and sodar data are available for comparison with simulated vertical wind profiles.

\section{Results and Discussion}

\subsection{Frequency and Characteristics of Gap Wind Events}

We identified 31 event days in the observed dataset out of the 60-day measurement period (Table 1). Event days occur in clusters of two or three days, except in early September when 10 event 
days occur in a row (Table 1). All of the event days have a favorable pressure gradient at $0600 \mathrm{LT}$ ranging from 0.2 to $1.8 \mathrm{~Pa} \mathrm{~km}^{-1}$ with an average of $1.0 \mathrm{~Pa} \mathrm{~km}^{-1}$. Non-event days did not have a favorable pressure gradient. The correlation with sea level pressure is discussed further in Section 3.2.

Here we report winds measured at a single sensor, NM3, for correlation with the surface pressure gradient on all classified event days. Sensor NM3 was located on the north canyon wall about one-third of the way up. As noted previously, the strength of the gap flow varies with position in the canyon, with the strongest flows typically at the mid- and upper-elevation sensors. While upper-elevation sensors typically measured higher speeds during gap events than those at lower elevations, inspection of winds at NM3 is useful for quantifying the within-canyon gap flow strength. Inspection of a single sensor allows for comparison between event days and correlation with sea level pressure gradient.

Another approach would have been to use winds measured at all sensors to estimate a cross-sectional flow through the valley study area; however, several issues related to terrain complexity complicate this method. First, small-scale flow features induced by local terrain occasionally appeared to impact some sensors (e.g., local recirculation zones were measured, rather than the broader valley flow field). Second, there is not an actual "top" to the valley below which the flow is contained, so definition of a flow cross-section is problematic.

There is a significant $(p<0.01)$ correlation between the sea level pressure gradient at $0600 \mathrm{LT}$ and the hourly average (averaged over the $0900 \mathrm{~h}$ ) wind speed measured at NM3 at $0900 \mathrm{LT}$ on event days (Figure 3). The model coefficient of determination is 0.21 . Given the inherent complexity of the system, the fact that the sea level pressure gradient explains $21 \%$ of the variability in the strength of the gap flow winds seems encouraging. Additional mechanisms, particularly the vertical stability of the atmosphere, likely account for some of the variability in gap wind strength. Gap winds are likely stronger under more stable atmospheric conditions due to suppressed mixing between the canyon atmosphere and upper-level winds. Cloud cover and diurnal temperature variations along the canyon would be expected to affect atmospheric stability within the canyon.

The average wind direction at NM3 ranges from $129^{\circ}$ to $168^{\circ}$, which is roughly aligned with the valley axis in the study area. Hourly average speeds at NM3 range from 0.4 to $7.1 \mathrm{~m} \mathrm{~s}^{-1}$ and maximum speeds range from 4.6 to $12 \mathrm{~m} \mathrm{~s}^{-1}$ during gap wind events. The wind speed at NM3 is often higher at 0900 LT than 0600 LT or 1200 LT during gap flow events, although this is not always the case (Table 1).

Given that the typical diurnal cycle includes a transition from downslope/downvalley to upslope/upvalley around $0900 \mathrm{LT}$, it seems intuitive that the peak in the gap wind strength would coincide with the peak in downvalley winds (sometime earlier in the morning) rather than around the transition time. However, if the gap events are canyon-scale events, it seems possible that there is momentum building over the early morning hours, as cooler, denser, more stable air from upcanyon makes its way downcanyon and eventually into the study area. The gap wind events typically lasted 6-7 h, so it is possible that colder, denser air from upcanyon would be entering the study area around 0900 LT. This is one possible explanation for the later peak in the gap wind strength. 


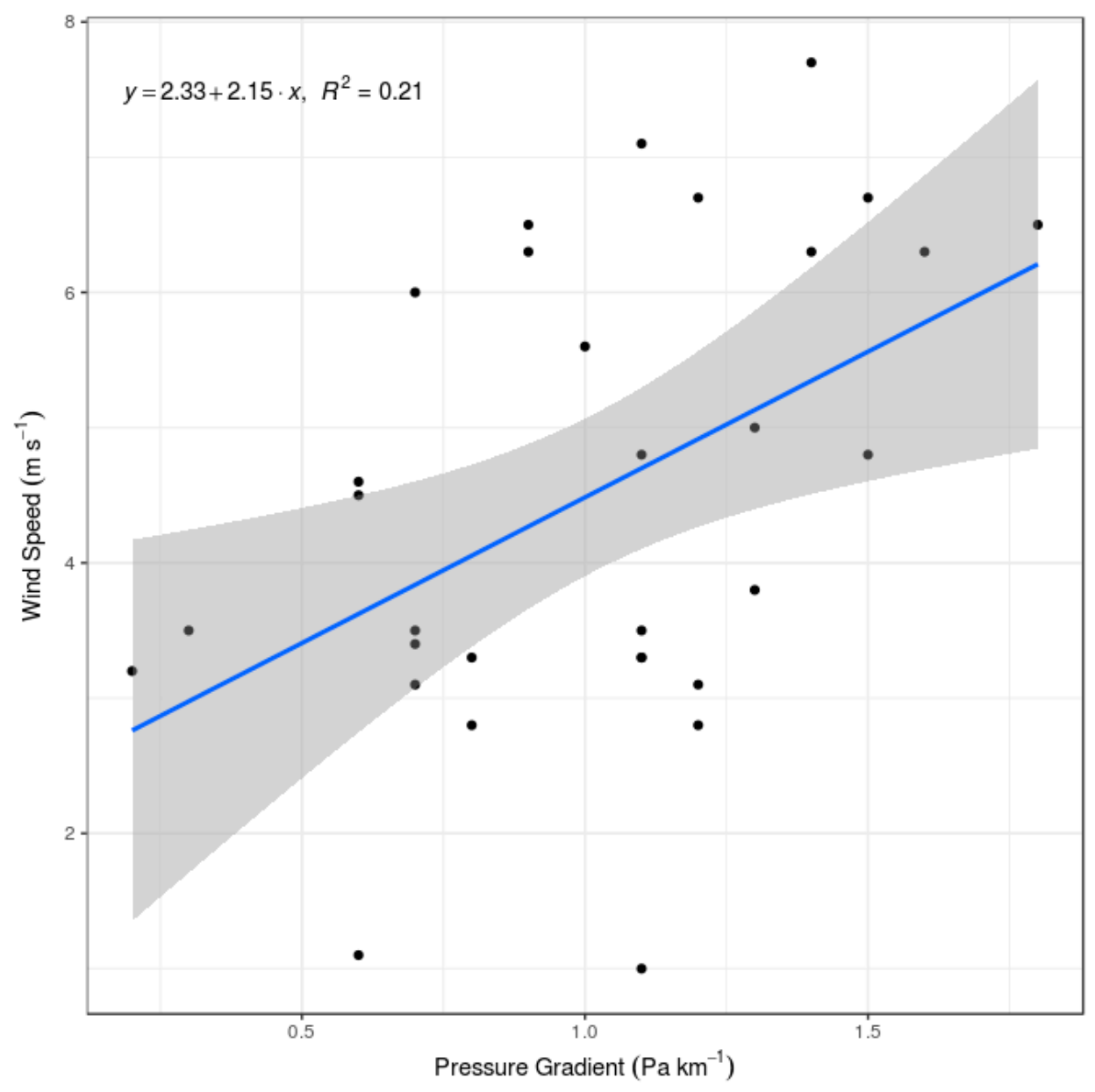

Figure 3. Relationship between the mean sea level pressure gradient at $0600 \mathrm{LT}$ and wind speed at sensor NM3 at 0900 LT. Gray shading indicates the $95 \%$ confidence interval.

Figure 4 shows the 10-min average winds at the top of each hour observed at sensors NM3 and NM1 during 15-19 August. Sensor NM1 was located about $300 \mathrm{~m}$ above NM3 (Figure 1). Two gap wind events (16 and 17 August) occur during this period (Figure 4). The data at NM3 indicate organized flow from the east with speeds above $9 \mathrm{~m} \mathrm{~s}^{-1}$ during the morning hours of the event days (Figure 4). Winds at NM1 have a more easterly direction than the winds at NM3 during the events on 16 and 17 August (Figure 4), likely because NM1 was closer to the ridgetops where the flow was less constrained by the valley sidewalls. Deeper within the valley at NM3, the winds are more aligned with the valley axis in accordance with mechanical channeling (e.g., [2]). Peak wind speeds during the gap events on 16 and 17 August are higher at NM1 than NM3 (9.5 vs. $5.0 \mathrm{~m} \mathrm{~s}^{-1}$ on 16 August and 10 vs. $7.1 \mathrm{~m} \mathrm{~s}^{-1}$ on 17 August) (Figure 5). The peak speeds also occur about two hours earlier at NM1 than NM3 (Figure 4). These characteristics are consistent with gap flow behavior.

Non-event days 15, 18 and 19 August transition from downslope/downvalley flow to upslope/upvalley flow around 0900 LT (Figure 4). Afternoon wind speeds on 15 August are stronger and more westerly at NM1 than on 18 and 19 August which could be from downward transport of horizontal momentum into the canyon (Figure 4). Non-event days 18 and 19 August more closely exhibit the typical diurnal cycle, with lighter afternoon winds and a stronger upslope component at NM3 than on 15 August (Figure 4). 


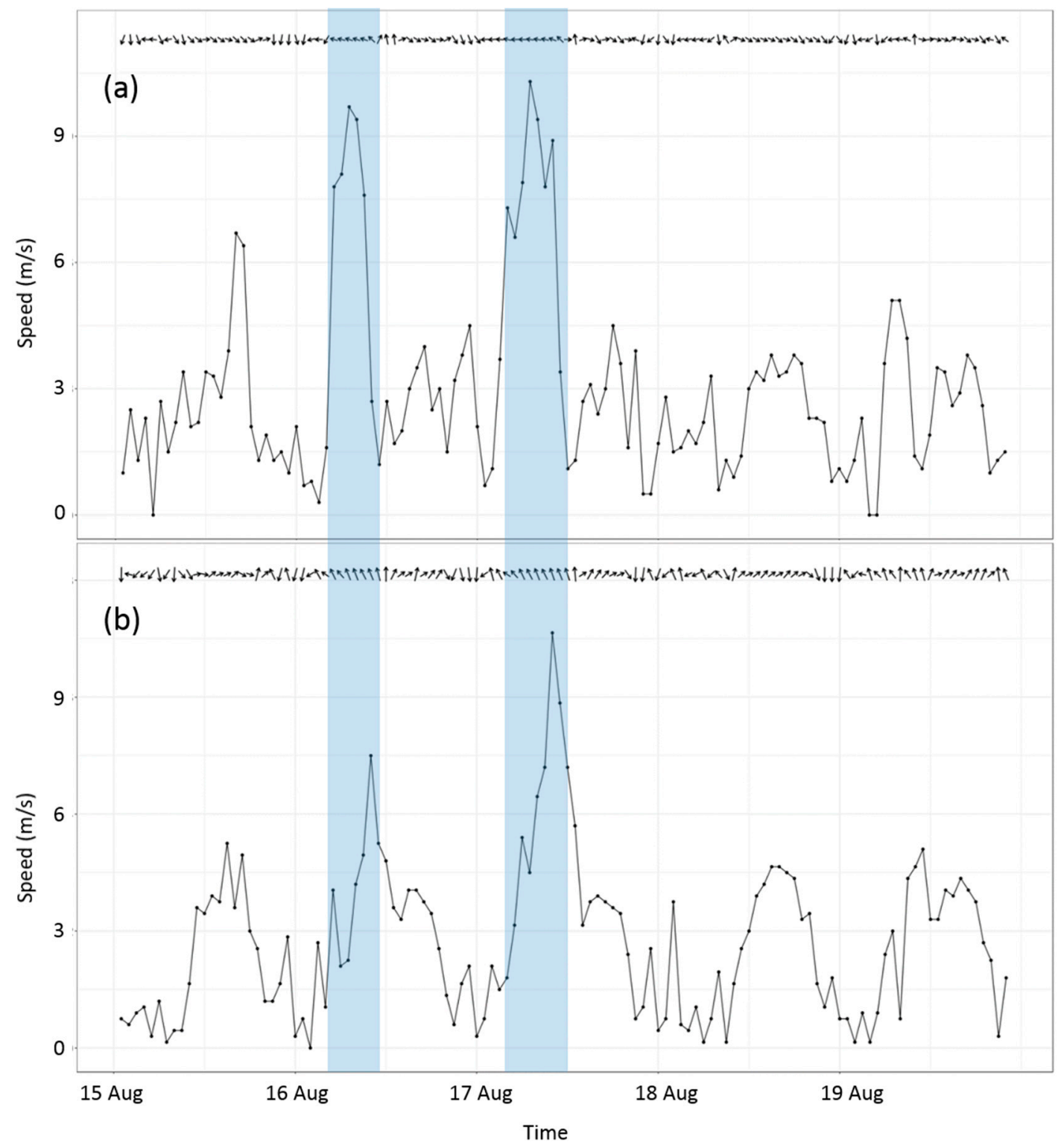

Figure 4. The 10-min average winds observed at the top of each hour at sensor: (a) NM1; and (b) NM3. The blue shading highlights two gap wind events.

The morning transition is further detailed by the vertical wind profiles measured at 0900 LT by a sodar located at river level on 17 and 18 August (Figure 5). On non-event day 18 August an upvalley flow layer approximately $120 \mathrm{~m}$ deep is established, eroding the previous night's residual downvalley flow layer from the ground up. The sodar data on event day 17 August shows downvalley flow at all heights with higher speeds between 200 and $300 \mathrm{~m}$ above ground level (AGL) than closer to the surface (Figure 5).

Note that the sodar data only extend up to $300 \mathrm{~m}$ AGL (roughly the height of sensor NM3), which is still within the canyon (approximately $700 \mathrm{~m}$ below the ridgetops). Thus, the vertical wind profiles shown in Figure 5 only characterize the lower third of the full valley depth. Sodar profiles are for the valley core near the center of the study area. 

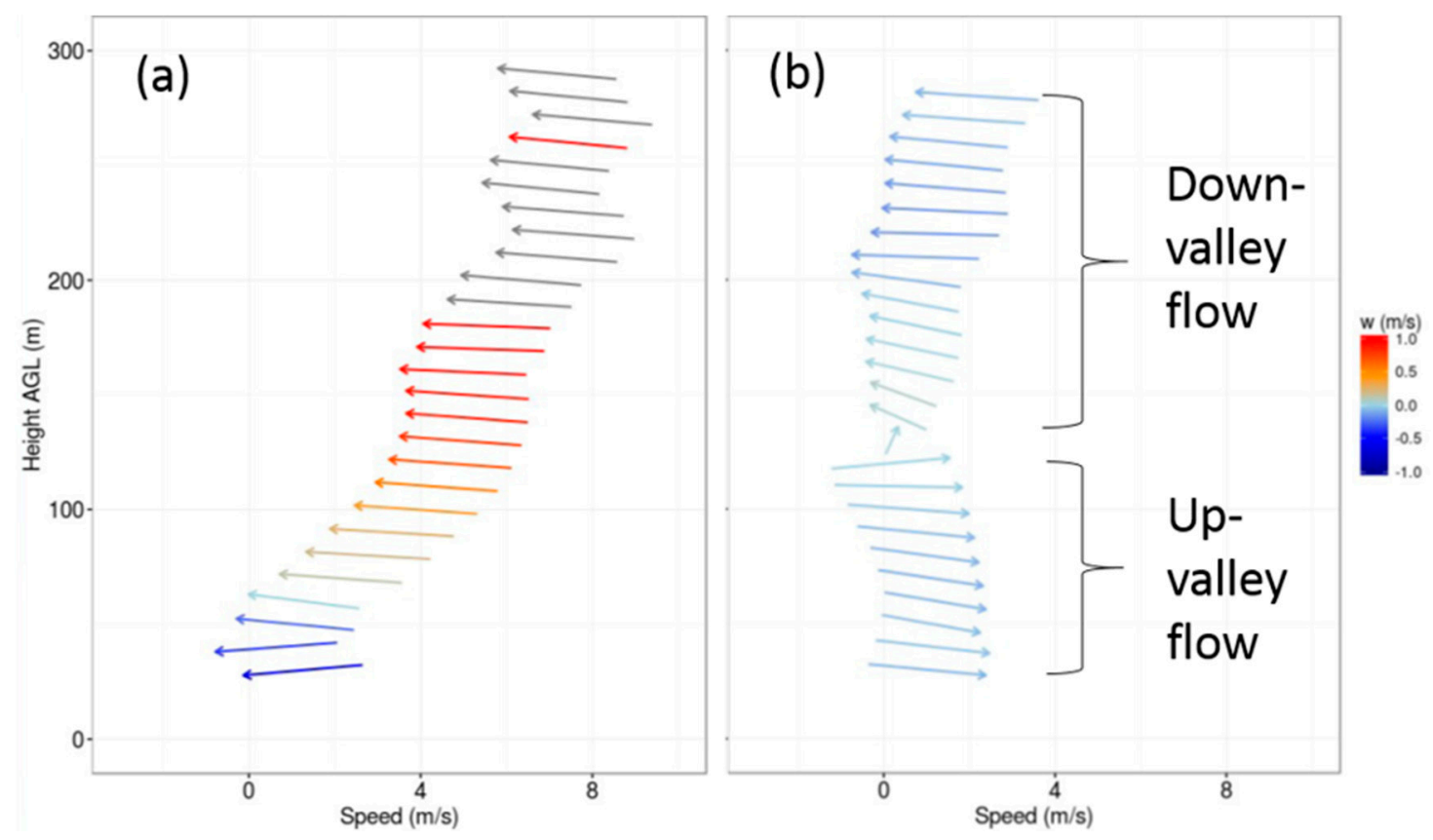

Figure 5. Vertical profiles of wind speed at 0900 LT measured by a sodar located at river level during: (a) a gap wind event on 17 Augus;t and (b) a non-event day on 18 August. The arrows are centered on the average speed measured at each height AGL. The direction of the arrow indicates the direction of the horizontal wind; arrows pointing left indicate wind from the east (downvalley wind). The arrow color indicates the $\mathrm{w}$-component of the wind.

\subsection{Correlation with Sea Level Pressure Gradient}

All event days have a favorable pressure gradient (decreasing pressure from east to west along the canyon) (Table 1). Non-event days are characterized by either an unfavorable (higher pressure to the west) or no pressure gradient (not shown). The ERA-Interim sea level pressure reanalyses for event day 17 August and non-event day 18 August are shown in Figure 6. A high pressure ridge is located directly over the eastern end of the Salmon River Canyon on event day 17 August (Figure 6b). On this day, sea level pressure decreases across the length of the canyon to a region of low pressure over eastern Washington and Oregon. On non-event day 18 August, there is low sea level pressure over central Idaho and higher pressure to the west (Figure $6 \mathrm{a}$ ). The $700-\mathrm{mb}$ winds are westerly on both days (not shown).

The clusters of event days appear to be linked to intermittent movement of synoptic-scale pressure systems. A near-surface inverted pressure trough (thermal trough) frequently forms over central Washington during summer months due to intense surface radiative heating in the arid Columbia Basin. A closed low pressure is evident in the Columbia Basin region on event day 17 August (Figure 6b); however, the closed low pressure is not evident on other event days, and instead there is a broader region of low pressure over Washington, Oregon, and northern Nevada and California. The West Coast thermal trough (WCTT) is the dominant mesoscale weather feature of the coastal western United States. The WCTT frequently migrates over the Columbia Basin of central Washington during summer months [14]. A northward migration of the Great Basin thermal trough is also common during the summer and would correspond to a broad region of low pressure extending into Oregon and Washington. Any of these mechanisms would provide a favorable pressure gradient for gap winds in the Salmon River Canyon. Inspection of sea level pressure maps for event days suggest that likely all three mechanisms contributed to formation of a favorable pressure gradient along the Salmon River Canyon during the study period (not shown). 

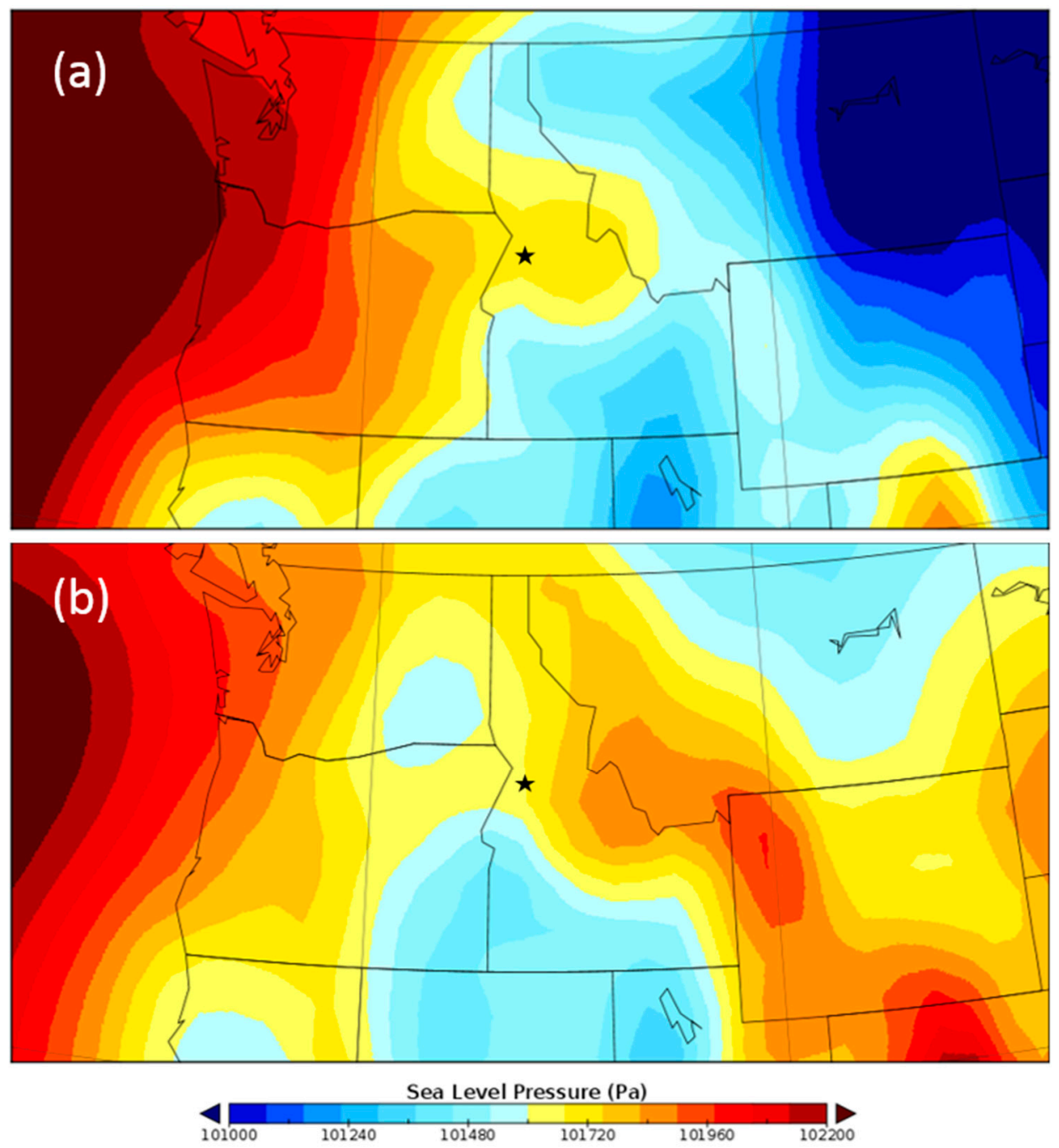

Figure 6. ERA-Interim sea level pressure analysis for 0600 LT on: (a) non-event day 18 August; and (b) event day 17 August. The study area is indicated with a star.

These synoptic-scale pressure patterns are often well-predicted by NWP and, thus, can be anticipated regionally. The predictability of regional sea level pressure patterns by operational NWP is discussed further in Section 3.4. Meteorologists and wildland fire managers should be aware of the potential for gap winds associated with regional sea level pressure gradients.

\subsection{Numerical Model Results}

\subsubsection{Simulation of Synoptic-Scale Patterns}

A favorable sea level pressure gradient is simulated for event day 17 August and an unfavorable sea level pressure gradient is simulated for non-event day 18 August in the $36 \mathrm{~km}$ domain (Figure 7), in agreement with the ERA-Interim sea level pressure reanalysis (Table 1 and Figure 6). A closed low pressure is simulated over the Columbia Basin on 17 August (Figure 7), which is also in agreement with the reanalysis. (Figure 6). 


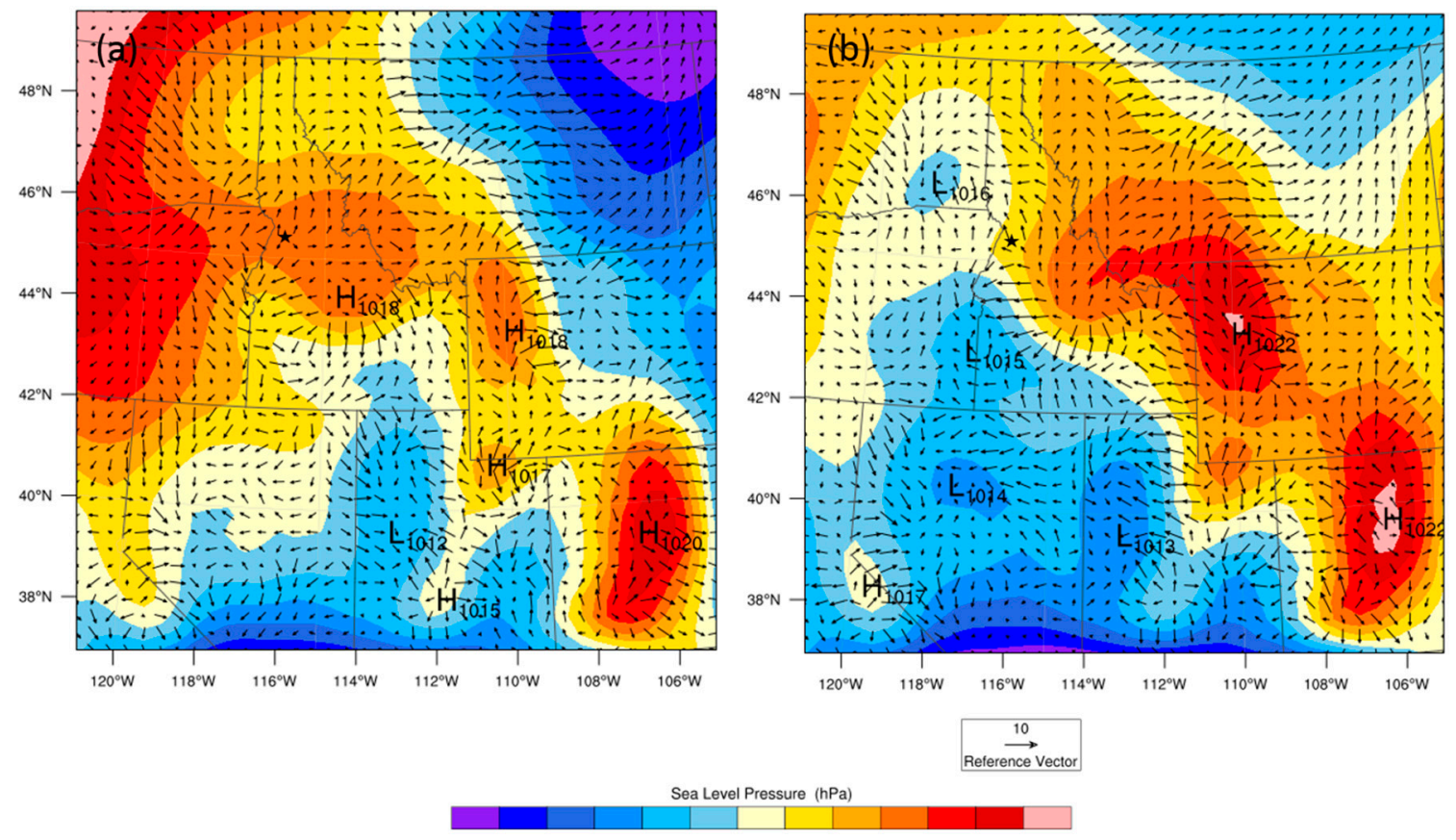

$10111012 \quad 1013 \quad 1014 \quad 101510161017 \quad 1018101910201021 \quad 1022$

Figure 7. Mean sea level pressure and 10-m winds simulated in the $36 \mathrm{~km}$ domain at $0600 \mathrm{LT}$ on:

(a) non-event day 18 August; and (b) event day 17 August. The study area is indicated with a star.

\subsubsection{The $1.33 \mathrm{~km}$ Domain}

Terrain representation in the $1.33 \mathrm{~km}$ domain is shown in Figure 8. The Salmon River Canyon and some of the smaller side drainages (e.g., Allison Creek, Crooked Creek, and South Fork Salmon River) are partially resolved. Terrain model elevations in the study area range from about $800 \mathrm{~m}$ at river level to $1400 \mathrm{~m}$ on the canyon walls. The actual river-level elevation in the study area is $540 \mathrm{~m}$ and the elevation at the northern end of the study area on the north side canyon wall is $1700 \mathrm{~m}$. The elevation difference in the terrain model is about $600 \mathrm{~m}$, while the actual terrain difference is about $1160 \mathrm{~m}$.

Figure 9 shows the simulated $10-\mathrm{m}$ and $700-\mathrm{mb}$ winds in the $1.33 \mathrm{~km}$ domain for $0900 \mathrm{LT}$ on event day 17 August. There is a clear decoupling between these levels. Downvalley flow is simulated throughout the study area at the $10-\mathrm{m}$ height, while the $700-\mathrm{mb}$ winds are westerly throughout the $1.33 \mathrm{~km}$ domain.

The maximum simulated 10-m speed is over the upper elevations of the north side canyon wall, near sensor NM1. The highest observed speeds during the 17 August event were at sensor NM1, with a maximum 10-min average speed of $10.3 \mathrm{~m} \mathrm{~s}^{-1}$ at $0700 \mathrm{LT}$ (Figure 5a). The 10-min average speed observed at $0900 \mathrm{LT}$ at NM1 is $7.8 \mathrm{~m} \mathrm{~s}^{-1}$ and the simulated speed is $4.6 \mathrm{~m} \mathrm{~s}^{-1}$, so the simulated speed was under-predicted by $3.2 \mathrm{~m} \mathrm{~s}^{-1}$ (Figures 5a and 9a). The observed speeds at NM1 vary from 3.4 to $10.3 \mathrm{~m} \mathrm{~s}^{-1}$ over the course of the event (Figure $5 \mathrm{a}$ ), but simulated speeds vary only from 2.5 to $4.6 \mathrm{~m}$ $\mathrm{s}^{-1}$. The downvalley flow is simulated, but the highest wind speeds and temporal variability are not. The results for event day 16 August are similar (not shown).

Downvalley flow is simulated not just within the study area, but also along the length of the canyon upstream from the study area on both event days 16 and 17 August (Figure 9a). We do not have measurements outside the study area for comparison, but the simulations suggest that the gap wind events are canyon-scale events and not limited to the study area. 


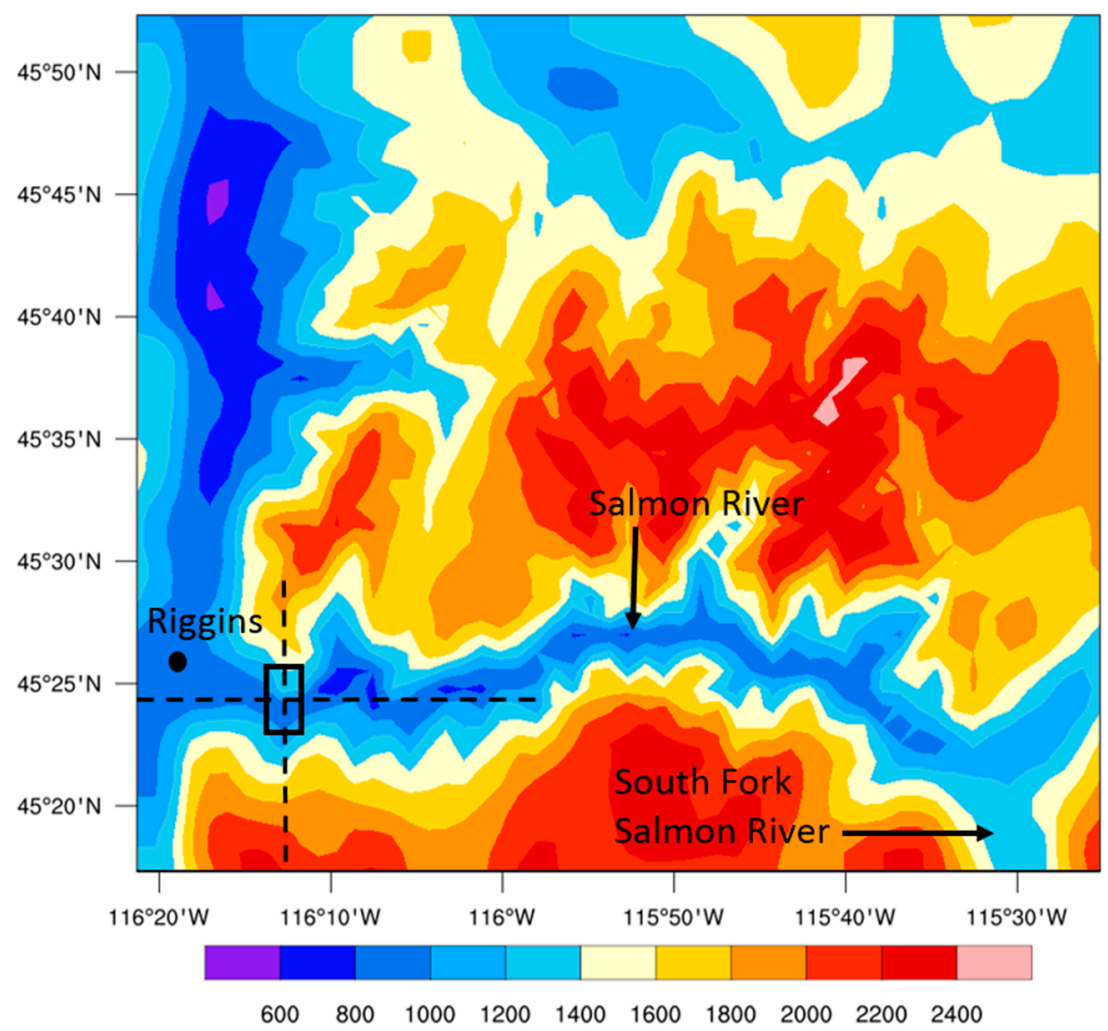

Figure 8. WRF $1.33 \mathrm{~km}$ domain with major geographical features and the study area labeled. Colors indicate terrain height in meters in the GMTED10 digital elevation model used for the simulations. The dashed black lines indicate transects along which vertical profiles are extracted for analysis.
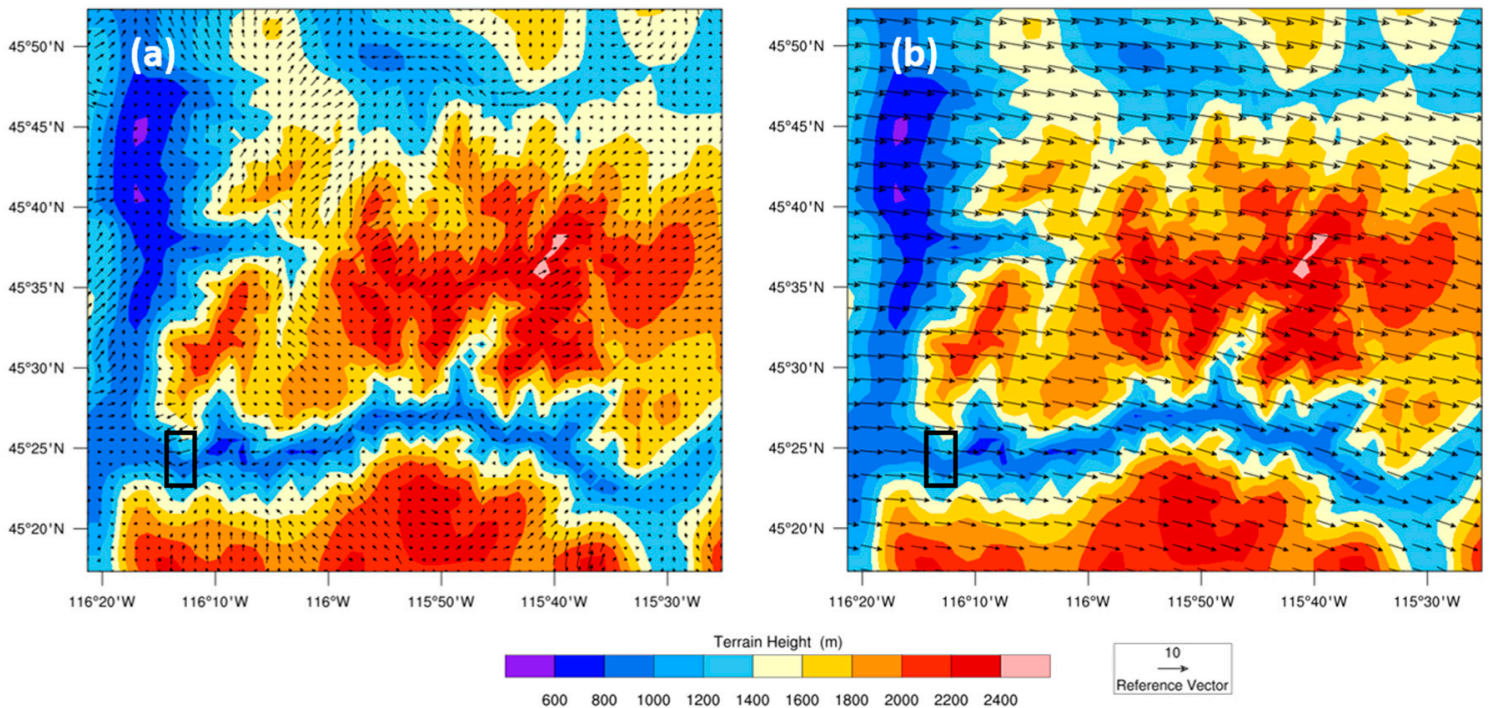

Figure 9. Simulated: (a) 10-m winds; and (b) 700-mb winds in the $1.33 \mathrm{~km}$ domain at $0900 \mathrm{LT}$ on event day 17 August. The black box delineates the study area.

Vertical profiles of the simulated winds and potential temperature are examined for two transects (one along-valley and one cross-valley) intersecting the study area (Figure 8). Along-valley vertical profiles during the morning of the simulated event on 17 August show a layer of downvalley flow between the surface and about $2000 \mathrm{~m}$, with a shallow stagnant layer above up to about $2300 \mathrm{~m}$ (Figure 10). Winds above the stagnant layer are westerly and generally increase with height. Between 
0600 and 0900 LT simulated winds are relatively constant, although the depth of the downvalley flow layer increases slightly and the stagnant layer shifts upward (Figure 10). By 1200 LT, the simulation is showing dissipation of downvalley flow at the surface, and, by 1500 LT, there is westerly (upvalley) flow throughout the vertical profile (Figure 10).
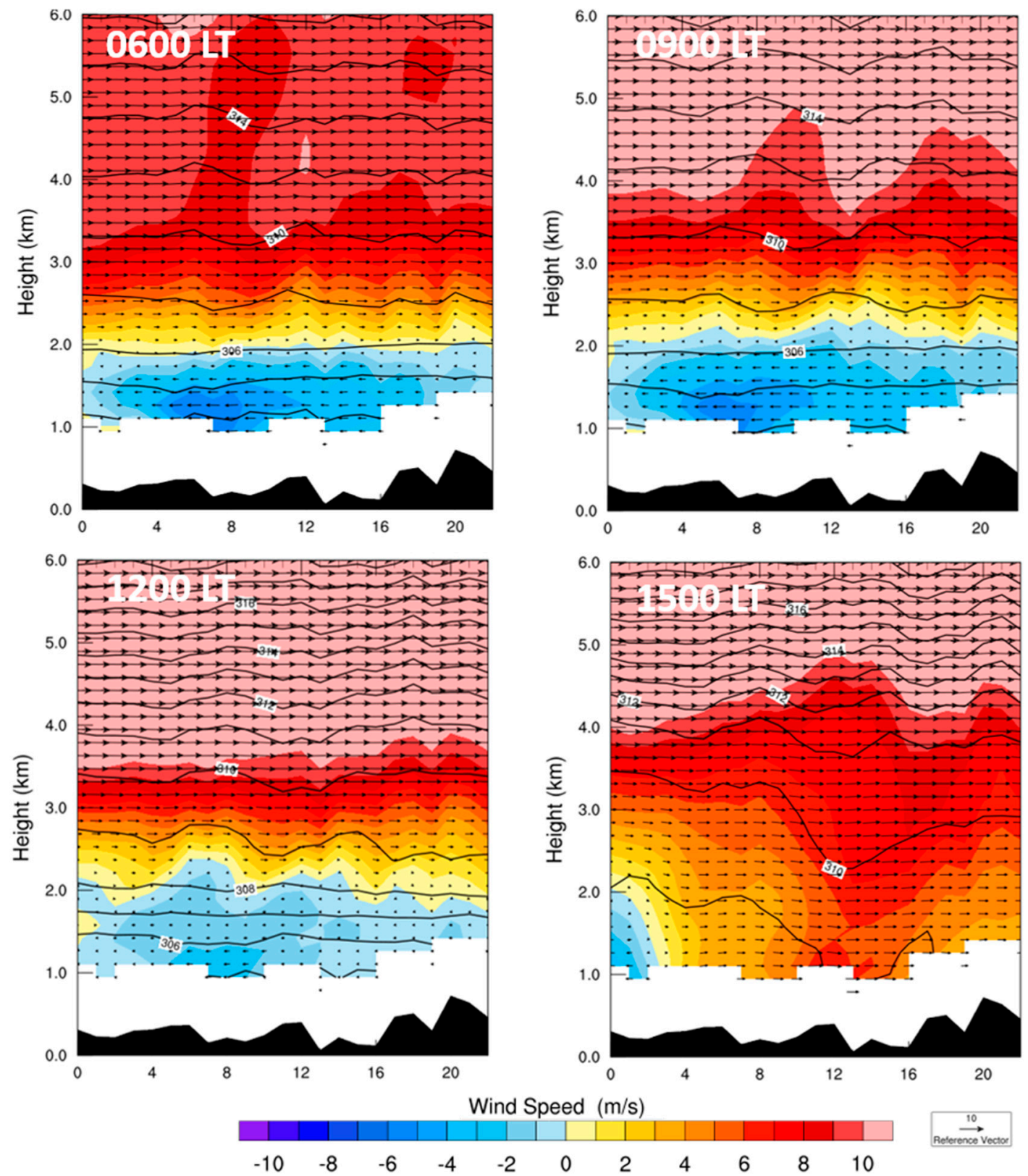

Figure 10. Along-valley vertical profiles of wind and potential temperature simulated in the $1.33 \mathrm{~km}$ domain for event day 17 August. Wind vectors indicate wind in the $x-z$ plane. Wind speed is the $\mathrm{u}$-component of the wind; negative values indicate easterly flow. The study area is located in cells 7-10 on the $x$-axis. Only the lowest $6 \mathrm{~km}$ are shown.

Cross-valley vertical profiles during the morning of the simulated event on 17 August show a core of downvalley flow near the center of the valley, but slightly offset over the south canyon wall (Figure 11). The near-surface ridgetop winds are light and westerly (upvalley) or stagnant during the morning period (Figure 11). Upper-level winds are from the southwest (Figure 11). By 1500 LT, upvalley winds of 3-4 $\mathrm{m} \mathrm{s}^{-1}$ are simulated in the valley center (Figure 11). 

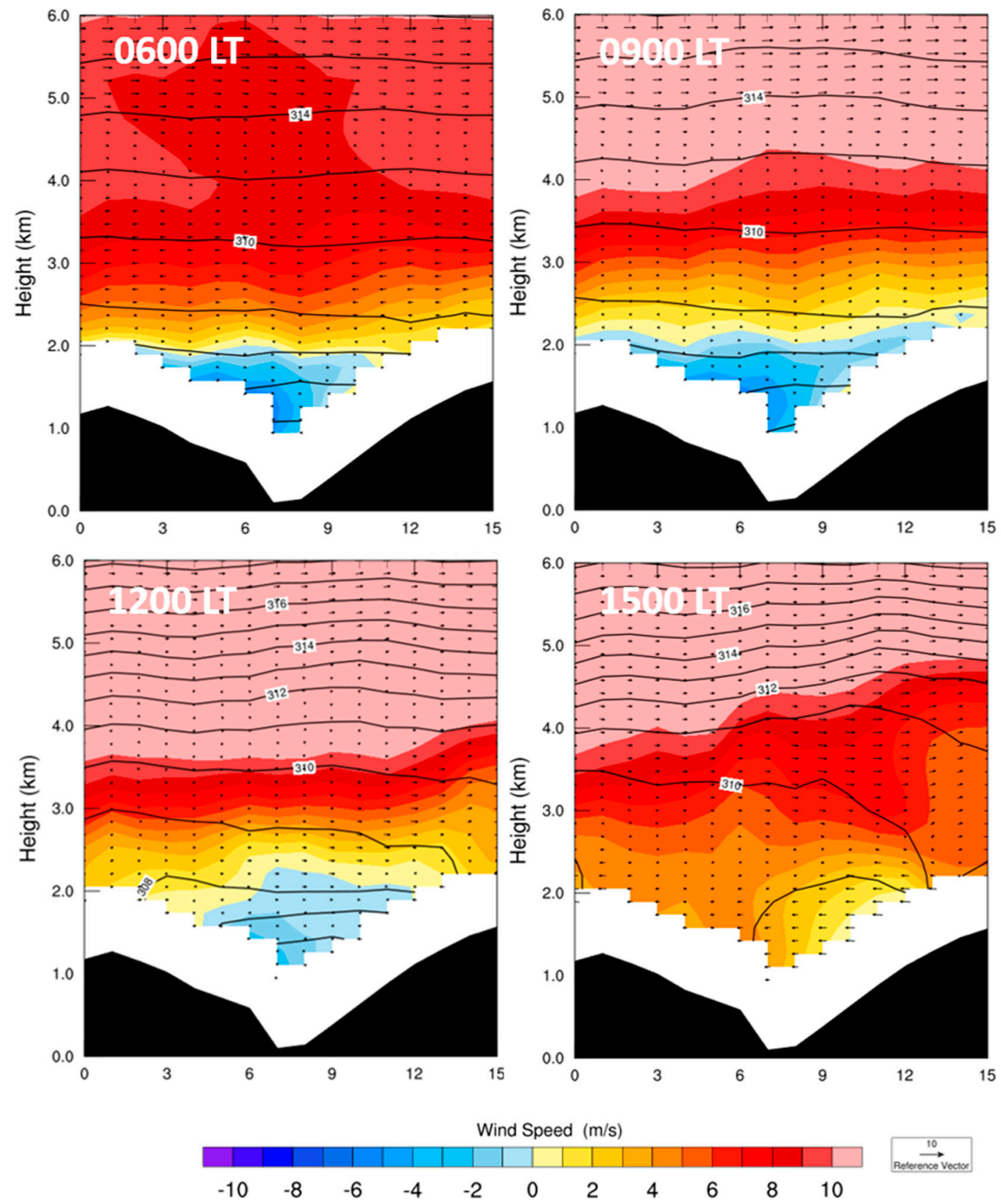

Figure 11. Cross-valley vertical profiles of wind and potential temperature simulated in the $1.33 \mathrm{~km}$ domain for event day 17 August. Wind vectors indicate wind in the $y$ - $z$ plane. Wind speed is the $\mathrm{u}$-component of the wind; negative values indicate easterly flow. Into the page is west with the north canyon wall on the right. Only the lowest $6 \mathrm{~km}$ are shown.

Simulations of non-event days 15, 18 and 19 August do not have downvalley winds during the late morning period as the simulations for the event days do. Instead, simulations for non-event days showed a transition from downvalley to upvalley flow around $0800 \mathrm{LT}$, which is in agreement with measurements.

Along-valley vertical profiles for non-event day 18 August are shown in Figure 12. On this day, simulated winds shift from nighttime downvalley winds to upvalley winds between $0600 \mathrm{LT}$ and 0900 LT (Figure 12). Simulated near-surface winds in the study area are weak (1-3 $\mathrm{m} \mathrm{s}^{-1}$ ) and do not have a clear along-valley component at 0600 LT (Figure 12). By 0900 LT simulated winds are upvalley 
between 1-4 $\mathrm{m} \mathrm{s}^{-1}$ (Figure 12). Between 0900 and 1500 LT, simulated upvalley surface winds increase to $6-7 \mathrm{~m} \mathrm{~s}^{-1}$. The within-canyon upvalley winds are aligned with the upper-level westerly winds.
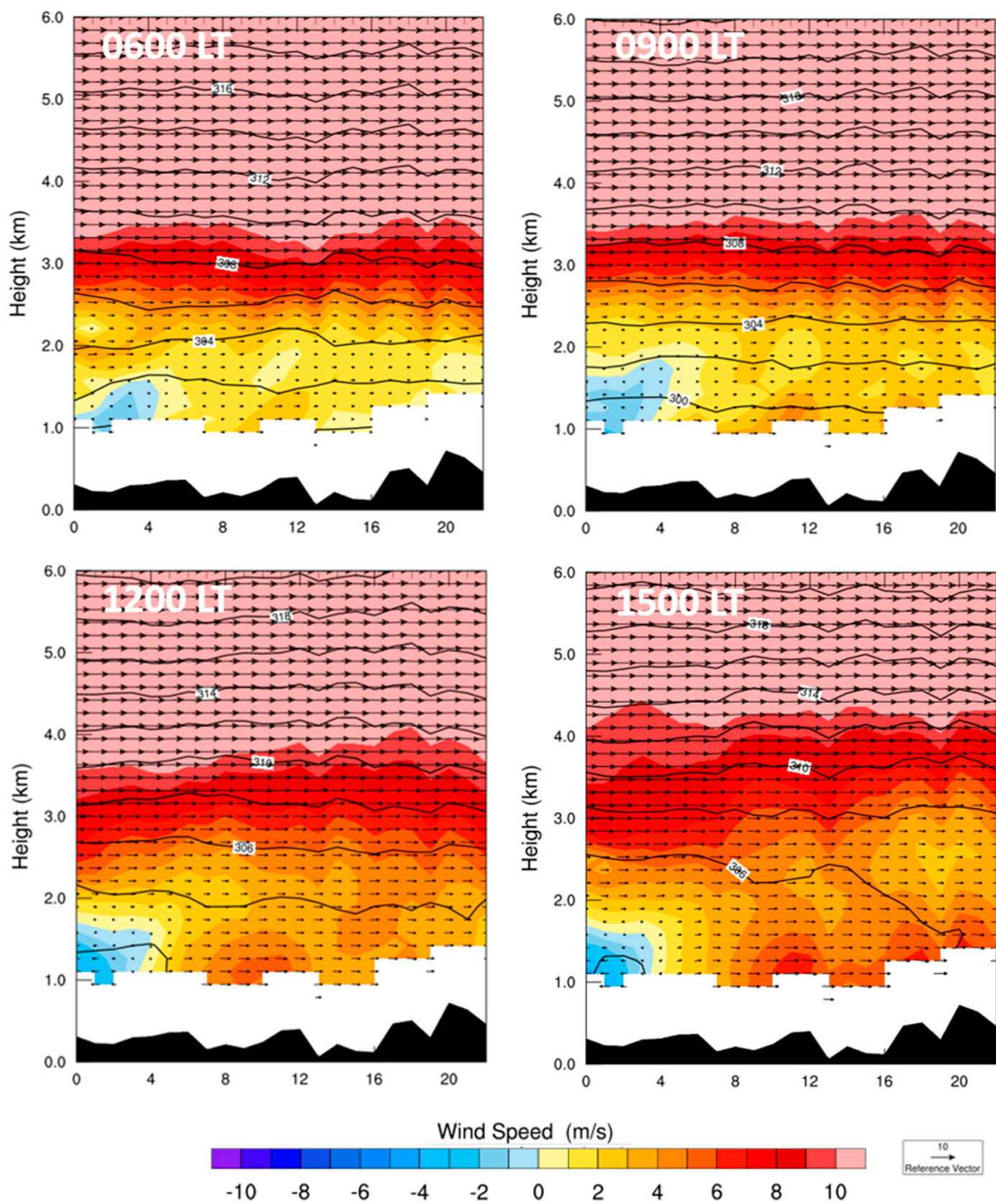

Figure 12. Along-valley vertical profiles of wind and potential temperature simulated in the $1.33 \mathrm{~km}$ domain for non-event day 18 August. Wind vectors indicate wind in the $x$-z plane. Wind speed is the $\mathrm{u}$-component of the wind; negative values indicate easterly flow. The study area is located in cells 7-10 on the $x$-axis. Only the lowest $6 \mathrm{~km}$ are shown.

Upslope winds are not simulated during the morning of 18 August (Figure 13), presumably due to insufficient vertical resolution in the model, although they were observed in the study area. Upvalley winds of 1-5 $\mathrm{m} \mathrm{s}^{-1}$ are simulated near the surface over the valley axis (Figure 13). The simulated upvalley winds are aligned with the westerly winds simulated in the upper levels of the domain (Figure 13). In the afternoon, there is an obvious northerly component to the simulated upvalley flow from the surface up to about $2500 \mathrm{~m}$ (Figure 13); this is because the valley is oriented 
along a slightly northwest-southeast angle in the study area (Figure 8). Simulated winds well above the ridgetops of the canyon do not have this northerly component (Figure 13).
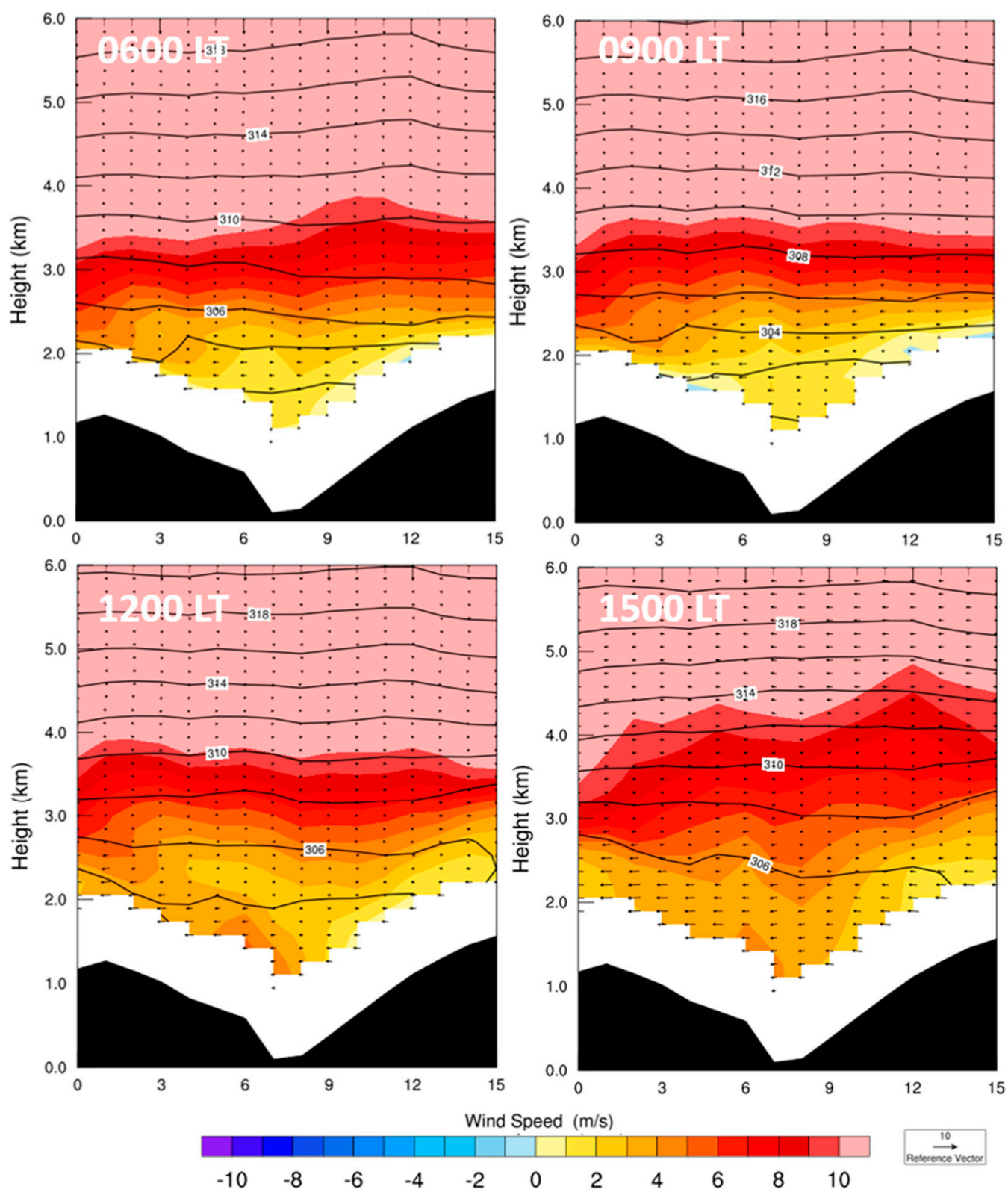

Figure 13. Cross-valley vertical profiles of wind and potential temperature simulated in the $1.33 \mathrm{~km}$ domain for non-event day 18 August. Wind vectors indicate wind in the $y$ - $z$ plane. Wind speed is the $\mathrm{u}$-component of the wind; negative values indicate easterly flow. Into the page is west with the north canyon wall on the right. Only the lowest $6 \mathrm{~km}$ are shown.

Another notable difference between event and non-event days is the degree of stratification within the valley atmosphere. On event day 17 August, the valley atmosphere is strongly stratified during the morning hours, as indicated by the higher density of the potential temperature isolines near the surface as compared to in the free troposphere above the valley (Figures 10 and 11). On non-event day 18 August, however, there is no increased stratification within the valley atmosphere compared to the free troposphere above the valley (Figures 12 and 13). Stronger stratification on event days likely facilitates formation of stronger gap flows in the canyon due to increased decoupling between the valley atmosphere and the free atmosphere above the valley. 


\subsubsection{Horizontal Grid Spacing and Terrain Representation}

We also investigate the simulated winds in the $4 \mathrm{~km}$ domain since a $4 \mathrm{~km}$ horizontal grid spacing is representative of the grid spacing commonly used for operational high-resolution NWP. We anticipated that the $4 \mathrm{~km}$ domain simulations would not show downvalley winds associated with the gap flow events due to the coarse horizontal resolution of the model (4 km grid spacing) compared to the width of the gap ( 2 km); however, the simulations in the $4 \mathrm{~km}$ domain show downvalley flow in the study area and along the canyon upstream at 0900 LT on event day 17 August. Along-valley vertical profiles of simulated wind and potential temperature confirm that downvalley flow is simulated near the surface along the valley axis in the $4 \mathrm{~km}$ domain (Figure 14).
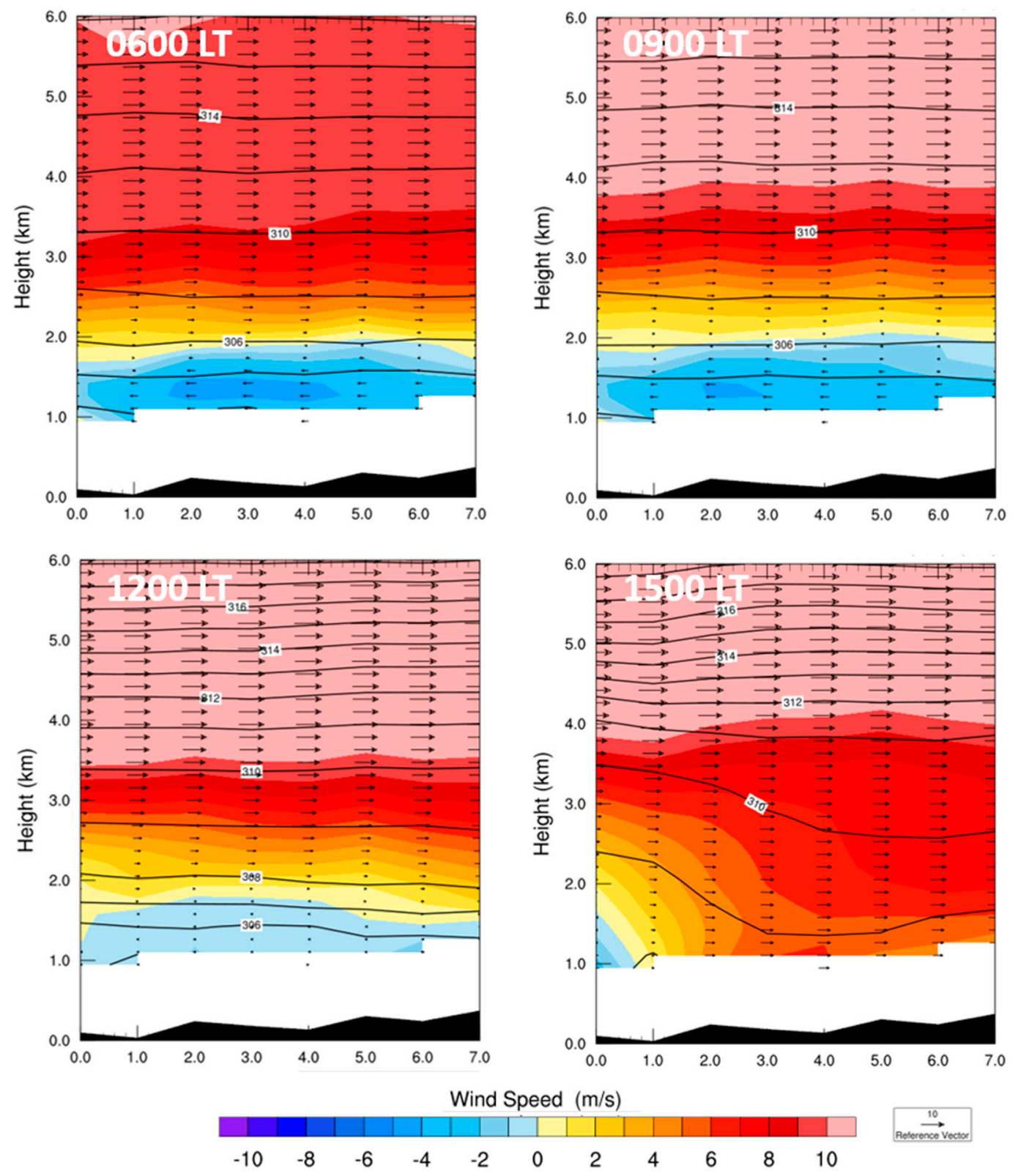

Figure 14. Along-valley vertical profiles of wind and potential temperature simulated in the $4 \mathrm{~km}$ domain for event day 17 August. Wind vectors indicate wind in the $x-z$ plane. Wind speed is the $\mathrm{u}$-component of the wind; negative values indicate easterly flow. Only the lowest $6 \mathrm{~km}$ are shown. 
When defined by the nearest ridgelines, the gap is approximately $2 \mathrm{~km}$ wide in the study area and narrower in portions of the upstream canyon. This gap is not adequately resolved by the $1.33 \mathrm{~km}$ domain and is not resolved at all by the $4 \mathrm{~km}$ domain. Only one or two grid cells cover the gap in the north-south direction in the $1.33 \mathrm{~km}$ domain and the gap is covered entirely by a single grid cell in the $4 \mathrm{~km}$ domain. The smallest-sized horizontal feature that can be adequately resolved in a NWP model has a size of six to eight times the model horizontal grid spacing [13]. Thus, the $1.33 \mathrm{~km}$ domain can only adequately resolve terrain features with horizontal scales of $5.3 \mathrm{~km}$ and larger. The $4 \mathrm{~km}$ domain can only adequately resolve terrain features with horizontal scales of $16 \mathrm{~km}$ and larger.

The gap defined by the nearest ridgelines is not properly resolved in the model; however, the gap could also be defined by higher ridgelines to the north and south of the river corridor. If the gap were instead delineated by the Salmon River watershed, the width would be considerably larger $(\sim 50 \mathrm{~km})$; this is illustrated in the elevation profiles in Figure 1a. The Salmon River watershed is resolved by both the $1.33 \mathrm{~km}$ and $4 \mathrm{~km}$ domains. Because the Salmon River canyon is a regional-scale depression situated between the Clearwater Mountains to the north and the Selway-Bitterroot Mountains to the south, gap flows are simulated in both domains when a favorable sea level pressure gradient exists.

The simulated events are affected by the poor terrain resolution, however. Because of the low resolution, valley depth is underestimated and the strength of the downvalley flows is under-predicted at least in part due to terrain misrepresentation (smoothing). The within-canyon stratification and associated flow decoupling are likely under-predicted. Simulated speeds are lower in the study area in the $4 \mathrm{~km}$ domain (Figure 14) than in the $1.33 \mathrm{~km}$ domain, and simulated speeds in the $1.33 \mathrm{~km}$ domain (Figures 12 and 13) are up to $40 \%$ lower than observed in the study area (Figure 5).

The $1.33 \mathrm{~km}$ horizontal grid spacing is near the practical limit for horizontal resolution in WRF due to discretization issues in steep terrain associated with the finite-difference method used in the model and use of planetary boundary layer (PBL) schemes for Reynolds-Averaged Navier-Stokes (RANS) turbulence closure that are not valid in complex terrain. Because of these limitations, finer horizontal grid spacings are not investigated.

\subsection{Gap Winds and Operational Modeling}

The fact that gap flow was simulated in the $4 \mathrm{~km}$ domain suggests that routine high-resolution NWP should be able to predict the gap flow events. To investigate this, we obtained archived experimental $3 \mathrm{~km}$ High-Resolution Rapid Refresh (HRRR) [30] and 4 km WRF simulations performed by the University of Washington (UW-WRF) for event day 17 August. The HRRR is currently the highest resolution operational forecast covering the contiguous United States; however, the 2011 forecasts investigated here are from an early experimental version of the HRRR, denoted hereafter as HRRRx11 to avoid confusion with the operational HRRR, which received substantial data assimilation and model physics upgrades before it was implemented operationally in 2014. The $4 \mathrm{~km}$ UW-WRF domain is the highest resolution domain in the UW-WRF system covering the Salmon River Canyon (UW-WRF also includes a $1.33 \mathrm{~km}$ domain, but it does not extend far enough east to cover the study area).

HRRRx11 was initialized with the $13 \mathrm{~km}$ Rapid Update Cycle (RUC) model (the HRRR is now initialized with the Rapid Refresh (RAP) model) and had no data assimilation. The RUC did not simulate the thermal low over eastern WA or the favorable east-west sea level pressure gradient that the $36 \mathrm{~km}$ WRF reanalysis simulation did (Figure $7 \mathrm{~b}$ ). Gap flow was not predicted in the HRRRx11 simulation, presumably because the regional sea level pressure gradient was incorrectly simulated.

A favorable east-west sea level pressure gradient was simulated in the UW-WRF system, which is in agreement with our reanalysis simulation (Figure 7b). The UW-WRF simulations show downvalley flow along the length of the canyon during the morning of event day 17 August; however, the simulated flow in the study area is weaker $\left(1-3 \mathrm{~m} \mathrm{~s}^{-1}\right)$ than that modeled in the reanalysis simulations. Additionally, the UW-WRF modeled flow is not consistently downvalley throughout the morning hours; some hours exhibit southerly or northerly flow over the study area. 
Thus, it appears that if the regional sea level pressure gradient is simulated correctly, the gap winds in the Salmon River Canyon can be simulated by high-resolution operational NWP modeling, although the strength of the gap winds may be substantially under-predicted. It is not clear why the RUC did not simulate the regional sea level pressure gradient correctly on the morning of 17 August, but the WRF-UW system did. It could be due to differences in data assimilation, methods used for reduction to mean sea level pressure, or differences in PBL, land-surface, or radiation schemes between the models.

There is some evidence to suggest that differences in the method used for reduction to mean sea level pressure could be the culprit. Differences in the pressure reduction method can introduce errors during interpolation of pressures from coarser to finer grids during model initialization over complex terrain. Brewer et al. [14] report that the Shuell pressure reduction [31,32] used in the NARR often results in a closed low pressure over eastern Washington and pressure ridging over higher terrain during summer months, while the Mesinger pressure reduction [33] (e.g., used in the Eta Model) does not produce either of these features. The Mesigner method was developed to mitigate "unnatural-looking" small-scale terrain-following features in the pressure field [34]. The RUC model uses the MAPS pressure reduction [35], which was also designed to provide a smoother sea level pressure surface.

Use of these different pressure reduction methods could explain why the NARR reanalysis runs for 17 August produced a favorable sea level pressure gradient with a closed low over central Washington and associated gap winds in the Salmon River Canyon, but the HRRRx11 (initialized with the RUC model) did not predict either. Brewer et al. [14] discuss the notion that certain meso-scale pressure structures, including the thermal trough over eastern Washington may simply be artifacts of faulty pressure reduction methods rather than physical features in the pressure field. The analysis in the current work, however, suggests that the thermal trough and ridging over the high terrain of western Montana and central Idaho are in fact physical features resulting in a favorable sea level pressure gradient which drives the evolution and strength of gap winds in the Salmon River Canyon. Given the various pressure reduction schemes in use and potential sensitivity of simulated pressures to the chosen PBL, radiation, and land-surface schemes (which are not investigated in this work), it is not clear how well current operational NWP models might perform in terms of predicting these gap flow events.

\section{Conclusions}

In this work, gap winds measured in the Salmon River Canyon of central Idaho are found to be driven by a regional-scale sea level pressure gradient induced by a surface pressure low that intermittently forms over east-central Washington and Oregon during the summer. NWP modeling at 1.33 and $4 \mathrm{~km}$ horizontal grid spacing could simulate many aspects of the observed gap flow events, although the strength of the gap flow is underestimated at both model resolutions. The river canyon is not well-resolved by the $1.33 \mathrm{~km}$ domain and is not resolved at all by the $4 \mathrm{~km}$ domain; however, because the canyon is a regional-scale depression situated between the high-elevation Clearwater Mountains to the north and the Selway-Bitterroot Mountains to the south, gap flows are simulated in both domains when a favorable sea level pressure gradient exists. Thus, operational modeling should be able to predict these gap wind events. Two issues regarding prediction of gap wind events within routine modeling frameworks were identified: (1) difficulty simulating the regional sea level pressure gradient; and (2) underestimation of gap wind strength, likely due to terrain smoothing and possibly underestimation of the sea level pressure gradient. These findings are important for wildland fire applications as fires frequently occur in the Salmon River Canyon. Additionally, it is anticipated that these types of gap wind events occur in other narrow canyons under favorable pressure gradients.

Acknowledgments: The NCEP Reanalysis data was provided by the NOAA/OAR/ESRL PSD, Boulder, Colorado, USA, from their website at http:/ / www.esrl.noaa.gov/psd/. Thanks to Matthew Jeglum of the University of Utah for helpful discussions regarding NCEP/NCAR and ERA-Interim reanalyses. Thanks to Joseph Olson 
and Eric James of NOAA/ESRL Global Systems Division for information regarding the HRRR and HRRRx11, providing access to the HRRRx11 simulations, and for providing feedback on an early version of this manuscript. Thanks to Dave Ovens and Cliff Mass for providing access to the UW-WRF simulations. We also appreciate the thoughtful review and suggestions provided by two anonymous reviewers.

Author Contributions: N.W., B.L., C.G., and B.B. conceived and designed the experiments; N.W. performed the experiments; N.W. and A.I. analyzed the data. N.W., J.F., and C.G. wrote the paper.

Conflicts of Interest: The authors declare no conflicts of interest.

\section{References}

1. Zardi, D.; Whiteman, C.D. Diurnal Mountain Wind Systems. In Mountain Weather Research and Forecasting; Chow, F.K., De Wekker, S.F.J., Snyder, B.J., Eds.; Springer: Dordrecht, The Netherlands, 2013; Chapter 2; pp. 35-119.

2. Whiteman, C.D. Mountain Meteorology: Fundamentals and Applications; Oxford University Press: New York, NY, USA, 2000.

3. Butler, B.W.; Wagenbrenner, N.S.; Forthofer, J.M.; Lamb, B.K.; Shannon, K.S.; Finn, D.; Eckman, R.M.; Clawson, K.; Bradshaw, L.; Sopko, P.S.; et al. High-resolution observations of the near-surface wind field over an isolated mountain and in a steep river canyon. Atmos. Chem. Phys. 2015, 15, 3785-3801. [CrossRef]

4. Sharp, J.; Mass, C.F. Columbia Gorge Gap Winds: Their Climatological Influence and Synoptic Evolution. Weather Forecast. 2004, 19, 970-992. [CrossRef]

5. Armi, L.; Mayr, G.J. Stratified flow across an alpine crest with a pass: Shallow and deep flows. Q. J. R. Meteorol. Soc. 2007, 133, 459-477. [CrossRef]

6. Overland, J.E.; Walter, B.A. Gap winds in the Strait of Juan de Fuca. Mon. Weather Rev. 1981, 109, $2221-2233$. [CrossRef]

7. De Foy, B.; Clappier, A.; Molina, L.T.; Molina, M.J. Distinct wind convergence patterns in the Mexico City basin due to the interaction of the gap winds with synoptic flow. Atmos. Chem. Phys. 2006, 6, 1249-1265. [CrossRef]

8. Xie, S.; Xu, H.; Kessler, W.S.; Nonaka, M. Air-sea interaction over the eastern Pacific warm pool: Gap winds, thermocline dome, and atmospheric convection. J. Clim. 2005, 18, 5-20. [CrossRef]

9. Gohm, A.; Mayr, G.J.; Fix, A.; Giez, A. On the onset of bora and the formation of rotors and jumps near a mountain gap. Q. J. R. Meteorol. Soc. 2008, 134, 21-46. [CrossRef]

10. Cramer, O.P. Frequency of dry east winds over the northwest Oregon and southwest Washington. In Pacific Northwest Forest and Range Experiment Station; Research Paper 24; USDA/Forest Service: Portland, OR, USA, 1957; p. 19.

11. Graham, H.E. The Columbia Gorge wind funnel. Weatherwise 1953, 6, 104-107. [CrossRef]

12. Eidenshank, J.; Schwind, B.; Brewer, K.; Zhu, Z.; Quayle, B.; Howard, S. A project for monitoring trends in burn severity. Fire Ecol. 2007, 3, 3-21. [CrossRef]

13. Skamarock, W.C.; Klemp, J.B. A time-split nonhydrostatic atmospheric model for weather research and forecasting applications. J. Comput. Phys. 2008, 227, 3465-3485. [CrossRef]

14. Brewer, M.C.; Mass, C.F.; Potter, B.E. The west coast thermal trough: Climatology and synoptic evolution. Mon. Weather Rev. 2012, 140, 3820-3843. [CrossRef]

15. Brewer, M.C.; Mass, C.F.; Potter, B.E. The west coast thermal trough: Mesoscale evolution and sensitivity to terrain and surface fluxes. Mon. Weather Rev. 2013, 141, 2869-2896. [CrossRef]

16. Berrisford, P.; Kallberg, P.; Kobayashi, S.; Dee, D.; Uppala, S.; Simmons, A.J.; Poli, P.; Sato, H. Atmospheric conservation properties in ERA-Interim. Q. J. R. Meteorol. Soc. 2011, 137, 1381-1399. [CrossRef]

17. Kalnay, E.; Kanamitsu, M.; Kistler, R.; Collins, W.; Deaven, D.; Gandin, L.; Iredell, M.; Saha, S.; White, G.; Woollen, J.; et al. The NCEP/NCAR 40-year reanalysis project. Bull. Am. Meteorol. Soc. 1996, 77, 437-471. [CrossRef]

18. Mesinger, F.; DiMego, G.; Kalnay, E.; Mitchell, K.; Shafran, P.C.; Ebisuzaki, W.; Jovic, D.; Woollen, J.; Rogers, E.; Berbery, E.H.; et al. North American regional reanalysis. Bull. Am. Meteorol. Soc. 2006, 87, 343-360. [CrossRef]

19. Wedam, G.B.; McMurdie, L.A.; Mass, C.F. Comparison of model forecast skill of sea level pressure along the east and west coasts of the United States. Weather Forecast. 2008, 24, 843-854. [CrossRef] 
20. Chen, F.; Mitchell, K.; Schaake, J.; Xue, Y.; Pan, H.; Koren, V.; Duan, Y.; Ek, M.; Betts, A. Modeling of land-surface evaporation by four schemes and comparison with FIFE observations. J. Geophys. Res. Atmos. 1996, 101, 7251-7268. [CrossRef]

21. Thompson, G.R.; Rasmussen, R.M.; Manning, K. Explicit forecasts of winter precipitation using an improved bulk microphysics scheme. Part I: Description and sensitivity analysis. Mon. Weather Rev. 2004, 132, 519-542. [CrossRef]

22. Kain, J. The Kain-Fritsch convective parameterization: An update. J. Appl. Meteorol. 2004, 43, $170-181$. [CrossRef]

23. Mlawer, E.J.; Taubman, S.J.; Brown, P.D.; Iacono, M.J.; Clough, S.A. Radiative transfer for inhomogenous atmospheres: RRTM, a validated correlated-k model for the longwave. J. Geophys. Res. 1997, 102, 16663-16682. [CrossRef]

24. Dudhia, J. Numerical study of convection observed during the winter monsoon experiment using a mesoscale two-dimensional model. J. Atmos. Sci. 1989, 46, 3077-3107. [CrossRef]

25. Monin, A.S.; Obukhov, A.M. Basic laws of turbulent mixing in the surface layer of the atmosphere. Contrib. Geophys. Inst. Acad. Sci. USSR 1954, 24, 163-187.

26. Hong, S.-Y.; Noh, Y.; Dudhia, J. A new vertical diffusion package with an explicit treatment of entrainment. Mon. Weather Rev. 2006, 134, 2318-2341. [CrossRef]

27. Mass, C.F.; Albright, M.; Ovens, D.; Steed, R.; Maclver, M.; Grimit, E.; Eckel, T.; Lamb, B.; Vaughan, J.; Westrick, K.; et al. Regional environmental prediction over the Pacific Northwest. Bull. Am. Meteorol. Soc. 2003, 40, 1353-1366. [CrossRef]

28. Skamarock, W.C. Evaluating mesoscale NWP models using kinetic energy spectra. Mon. Weather Rev. 2004, 132, 3019-3032. [CrossRef]

29. Stauffer, D.R.; Seman, N.L. Multiscale four-dimensional data assimilation. J. Appl. Meteorol. 1994, 33, 416-434. [CrossRef]

30. Alexander, C.R.; Weygandt, S.S.; Benjamin, S.G.; Smirnova, T.G.; Dowell, D.C.; Hofmann, P.; James, E.J.; Hu, M.; Lin, H.; Brown, M.J.; et al. Evaluation of High Resolution Rapid Refresh (HRRR) Model Changes and Forecasts during 2011. In Proceedings of the American Meteorological Society Annual Meeting, New Orleans, LA, USA, 22-26 January 2012.

31. Mesinger, F.; Treadon, R.E. “Horizontal” reduction of pressure to sea level: Comparison against the NMC's Shuell method. Mon. Weather Rev. 1995, 123, 59-68. [CrossRef]

32. Stackpole. Revised Method of 1000 mb Height Computation in the PE Model; Technical Procedures Bulletin 57, NOAA/NWS; Stackpole: Mecklenicsburg, PA, USA, 1970; p. 6.

33. Mesigner, F. "Horizontal" pressure reduction to sea level. In Proceedings of the International Tagung fur Alpine Meteorologie, Schweizerische Meteorologische Anstalt, Engelberg, Switzerland, 17-21 September 1990; pp. 31-35.

34. Pauley, P.M. An example of uncertainty in sea level pressure reduction. Weather Forecast. 1998, 13, 833-850. [CrossRef]

35. Benjamin, S.G.; Miller, P.A. An alternative sea level pressure reduction and a statistical comparison of geostrophic wind estimates with observed surface winds. Mon. Weather Rev. 1990, 118, 2099-2116. [CrossRef]

(C) 2018 by the authors. Licensee MDPI, Basel, Switzerland. This article is an open access article distributed under the terms and conditions of the Creative Commons Attribution (CC BY) license (http://creativecommons.org/licenses/by/4.0/). 